\title{
THE GENUS PTEROSPERMA (PRASINOPHYCEAE): SPECIES WITH A SINGLE EQUATORIAL ALA
}

\author{
MARY PARKE, G. T. BOALCH, ROSEMARY JOWETT* AND \\ D. S. HARBOUR \\ The Laboratory, Marine Biological Association, Citadel Hill, Plymouth
}

(Plates I-XIV, Figs. 1-2)

The life-history of the genus Pterosperma Pouchet is described. Development of the two phases, motile and non-motile, is detailed and a lunar periodicity in their change over indicated. Only the motile phase can persist independently, the cells reproducing asexually by fission. Sexuality has not been recorded for the genus. Criteria for valid generic and specific separation are discussed. Detailed descriptions, synonomy, distribution records, a key and a comparative table of specific characters are given for seven species, each with a single equatorial ala, including four new species, Pterosperma eurypteron Parke, $P$. porosum Parke, $P$. inornatum Parke and $P$. citriforme Parke.

\section{CONTENTS}

\begin{tabular}{|c|c|c|c|c|c|c|c|c|c|c|c|c|}
\hline Introduction & . & . & . & . & . & . & . & . & . & . & $\cdot$ & 240 \\
\hline Acknowledgements & & . & . & . & . & . & . & . & . & . & & 241 \\
\hline Original description & & . & . & . & . & . & . & . & . & . & & 241 \\
\hline Type species & . & . & . & . & . & . & . & . & . & . & & 242 \\
\hline Synonomy . & . & . & . & . & . & . & . & - & . & · & & 242 \\
\hline \multicolumn{6}{|c|}{ Description of genus Pterosperma Pouchet } & . & . & . & . & . & & 243 \\
\hline Revised diagnosis & is of $\mathrm{g}$ & genus & . & . & . & . & . & & & & & 243 \\
\hline The phycoma ph & hase & & . & $\therefore$ & . & . & . & & & 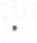 & & 244 \\
\hline ment $\mathrm{c}$ & of the & e phyc & oma $\mathrm{p}$ & ohase & . & . & . & & & & & 245 \\
\hline on of $t$ & the $\mathrm{m}$ & lotile $\mathrm{p}$ & phase & 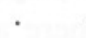 & . & & & & & & & 246 \\
\hline The mot & & & $\cdot$ & . & . & . & . & 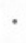 & & . & & 247 \\
\hline Characters of $t$ & the sc & cale co & vering & & . & . & . & & 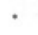 & 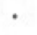 & & 247 \\
\hline Fission in the & motil & le phas & & . & . & . & . & & & 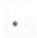 & & 249 \\
\hline Mode of swim & iming & & & & & . & . & & & . & & 249 \\
\hline Change from $n$ & motile & to $\mathrm{ph}$ & hycom & a phas & & . & . & . & ${ }^{\circ}$ & ${ }^{\circ}$ & & 250 \\
\hline \multicolumn{7}{|c|}{ Validity of criteria for generic and specific separation } & . & . & . & . & & 251 \\
\hline Generic characte & & . & . & . & . & . & . & 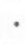 & . & 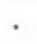 & & 251 \\
\hline Specif & & . & . & . & . & · & $\cdot$ & - & $\cdot$ & $\cdot$ & & 253 \\
\hline \multirow{2}{*}{\multicolumn{6}{|c|}{$\begin{array}{l}\text { Diagnoses and descriptions of species } \\
\text { Pterosperma rotondum Pouchet - type species }\end{array}$}} & . & . & . & . & . & & 254 \\
\hline & & & & & & . & . & . & & r. & & 2 \\
\hline \multicolumn{6}{|c|}{ Pterosperma moebii (Jørgensen) Ostenfeld } & 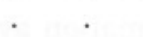 & . & . & . & . & & 2 \\
\hline \multicolumn{5}{|c|}{ Pterosperma eurypteron Parke, sp.nov. } & . & . & 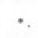 & . & . & . & & 2 \\
\hline \multirow{2}{*}{\multicolumn{5}{|c|}{$\begin{array}{l}\text { Pterosperma porosum Parke, sp.nov. } \\
\text { Pterosperma inornatum Parke, sp.nov. }\end{array}$}} & . & . & . & . & . & . & & \\
\hline & & & & & . & . & 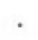 & & & & & 262 \\
\hline \multirow{2}{*}{\multicolumn{5}{|c|}{$\begin{array}{l}\text { Pterosperma undulatum Ostenfeld } \\
\text { Pterosperma citriforme Parke, sp.nov. }\end{array}$}} & . & . & . & . & & . & & 263 \\
\hline & & & & & & . & ${ }^{\circ}$ & . & . & ${ }^{\circ}$ & & 265 \\
\hline \multicolumn{7}{|c|}{ Key to species of Pterosperma (with a singl } & & ${ }^{\circ}$ & . & . & • & 269 \\
\hline References & . & . & . & . & . & . & . & . & . & . & . & 269 \\
\hline
\end{tabular}

* Mrs R. Waters, Institute of Oceanography, University of British Columbia, Vancouver 8, Canada. 


\section{INTRODUCTION}

This study of the genus Pterosperma followed on from our work on the genus Halosphaera (Parke \& Adams, 1961; Parke \& Hartog-Adams, 1965; Boalch \& Mommaerts, 1969) since while studying the latter we found abundant pterospermatacean material. In recent books on algae the family Pterospermataceae Ostenfeld (1902) is placed in the class Chrysophyceae (Papenfuss, 1955; Bourrelly, 1957, 1968; Fott, 1959, 1971 ; Prescott, 1969). The family, however, rightfully belongs in the class Prasinophyceae (Parke in Parke \& Dixon, 1964, 1968; Christensen, 1966) in the order Pterospermatales (Parke \& Green in Parke \& Dixon, 1976).

Up to now, information concerning the non-motile phycoma phase of members of the Pterospermataceae has been scanty, earlier workers considering them to be possible phytoplanktonic resting stages or crustacean eggs. The motile phase has never been recorded as such until now. Jørgensen (1900) assessed their true relationship by placing them in the Halosphaeraceae. He stressed that the living Pterospermataceae he studied contained large spheres of oil and were consequently almost always found in the surface waters. This statement does not hold true for their occurrence in the sea in general (Harbour, unpublished; Thorrington-Smith, 1970; see also Jeffrey, 1976) but when conditions are extremely calm surface blooms of members of the Halosphaeraceae and Pterospermataceae do occur. Because of this characteristic of rising to the surface very large numbers of phycomata can be obtained for culture and/or study by drawing off the surface film of a sample that had been left to stand undisturbed. The sedimentation method for plankton counting used by most investigators may well be responsible for loss of material belonging to the Pterospermataceae and consequently the very scanty records, or absence of records, in the literature for members of this family.

Although a number of early workers had observed the slits in empty Pterosperma phycoma outer walls (e.g. Hensen, 1887; Gran, 1902; Ostenfeld, 1903, 1910) and believed that the contents had been liberated, there are no published records of such a liberation having been observed. Schiller (1925, p. 72) did suggest that a motile phase might be liberated from the 'protococcal phase' and described in this work some Adriatic flagellates similar to motile cells of the Pterospermataceae. However, it is only now, more than eighty years after these organisms were first found, that we know that motile cells are produced by and liberated from the planktonic nonmotile phycoma.

Lohmann (1904, taf. III) summarized the information available at that time stating that members of the genus Pterosperma were widespread though never in large numbers. $\mathrm{He}$ emphasized the lack of information available concerning the systematic position of the genus and concluded that only future investigations, which must be carried out on living material, would give the information needed. This we have done and have found that all members of the genus Pterosperma investigated, in accord with the members of the genera Halosphaera (Manton, Oates \& Parke, 1963; Boalch \& Mommaerts, 1969) and Pachysphaera (Parke, 1966) we have studied, possess two phases in their lifehistory: a non-motile pelagic phycoma phase and motile flagellate phase. We have also found that the timings of the changeover from phycoma to motile and from motile to phycoma are related apparently to lunar periodicity. This finding is of paramount im- 
portance for researchers intending to study members of the Pterospermataceae in other areas.

Collections should be made with both $61 \mu \mathrm{m}$ ( 189 meshes/in) and $20 \mu \mathrm{m}$ ( 459 meshes/ in) tow-nets at both the surface and at $10 \mathrm{~m}$ depth just before or over the full and new moon periods. If, however, large supplies of young phycomata are needed, then collection should be made within $24 \mathrm{~h}$ of the new or full moon. Collection for mature material should be made about 4 days before the date of the new or full moon. If clean empty outer phycomata walls are needed for study, these should be collected a few days either side of the new or full moon.

Our studies have however shown us the difficulties that can be encountered in the recognition of Pterosperma species. Species cannot be recognized during their motile phase and some are difficult to identify during their phycoma phase unless the phycoma contents are removed. For example, the species most commonly recorded has been $P$. dictyon (Jørg.) Ostenf. but if we are to accept its original diagnosis then we have never found this species in our years of study. The most reliable method of identification of a Pterosperma species is therefore the study of the empty outer wall of the phycoma phase after the contents have been either released naturally or extruded artificially by the bursting of the outer wall.

We propose therefore to include, in addition to our own distribution records for Pterosperma species and those of the original authors of species, only those records emanating from the Department of Marine Botany in the University of Oslo, particularly those from Mrs K. R. Gaarder (1954 and unpublished records - personal communication) from whom we have had very generous co-operation.

Grateful acknowledgement for the collection of living material is given to Dr A. J. Southward, Mr E. I. Butler and the Captains and crews of the laboratory vessels, to Surgn Lt G. M. Welham, M.B., ChB., and Lt P. Norton of H.M. Survey Ships 'Welsh Consort' and 'Zula', to Dr N. Reynolds, Fisheries Laboratory, Lowestoft, and to Dr P. J. Williams, Department of Oceanography, University of Southampton.

We thank most sincerely the staff and research workers of the Department of Marine Botany of the University of Oslo - particularly Mrs K. R. Gaarder for putting at our disposal distribution records of Pterosperma species. Our sincere thanks are given also to Dr G. Y. Kennedy, Cancer Research Unit, University of Sheffield, for the pigment investigation of both phycoma and motile phase of Pterosperma showing the presence of chlorophyll $a$ and $b$ and Professor T. Christensen, University of Copenhagen, for translating the diagnoses for the new species into latin and for suggesting the name $P$. eurypteron for one of these species. Finally grateful thanks are given to Mrs J. Woollard, who has rendered such excellent technical assistance during the whole period of this investigation.

\section{ORIGINAL DESCRIPTION OF GENUS}

Pouchet (1893) placed two species in his genus Pterosperma and one of these, $P$. rotondum, is undoubtedly a representative of the genus as now delimited (Fig. $1 \mathrm{~A})$. His second species, P. ovatum (Fig. 1 B), could represent either a Pterosperma species under coverslip pressure (cf. Fig. 1 and Pl. VIIE) or a dinophycean cyst. Pouchet's diagnoses were as follows:

'Pterosperma rotondum Pouchet, rond, muni d'une membrane saillante circulaire;

Pterosperma ovatum Pouchet, ovoide, muni d'une crete membraneuse enveloppant l'entre d'après son grand axe et rappellant celles des Dinophysis.' 


\section{TYPE SPECIES}

A type species for the genus was not designated either by Pouchet or by subsequent workers. Bourrelly (1957) designated $P$. rotondum (but as $P$. rotondatum) as the type species for one section of the genus (the equatorial ala section) as now delimited. We therefore propose this species, $P$. rotondum Pouchet (1893, p. 178, fig. 18A), as the type species of the genus Pterosperma Pouchet 1893 as now considered. The figure of $P$. rotondum given by Pouchet is not good but is sufficiently clear to permit identification as a Pterosperma; in the absence of a specimen this figure (Pouchet, 1893, p. 178, fig. $18 \mathrm{~A}$ ) is here designated as the lectotype of the type species $P$. rotondum Pouchet.
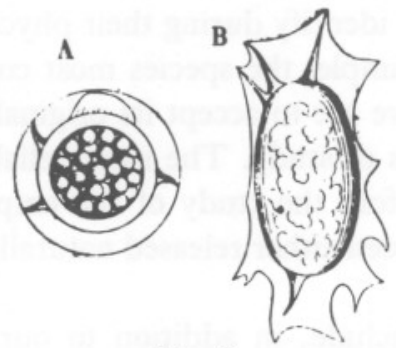

Fig. 18.

A. Pterosperma rotondun Pouchet. - B. P. oratum Pouchet.

Fig. 1. Pterosperma rotondum Pouchet lectotype. Reproduced from the drawing published to illustrate the original description of the new genus and species (Pouchet, 1893, p. 178, fig. 18 A).

\section{SYNONYMY}

Phycoma phase

Pterosphaera Jørgensen (1900, p. 47)

Cysta Cleve (1900, p. 18)

Trochiscia sensu Lemmermann (1903, p. 347, proparte) nec Trochiscia Kützing (1845, p. 129)

Pterocystis Lohmann (1904, p. 44)

Pterosphaera (Jørgensen) Lohmann (1904, p. 45)

Pterococcus ${ }^{\star} \dagger$ Lohmann (1904, p. 47)

Cymatiosphaera O. Wetzel (1933, p. 27)

Pterospermopsis W. Wetzel (1952, p. 411)

Pterospermella Eisenach (1972, p. 597)

\section{Motile phase}

?Cymbomonas J. Schiller (1913, p. 626)

* Coccopterum Silva, 1970 = Pterococcus Lohmann non Pterococcus Pallas nec Pterococcus Hasskarl.

† Dinophycean cyst according to Wall \& Dale (1968, p. 270). 


\section{DESCRIPTION OF GENUS PTEROSPERMA POUCHET}

\section{REVISED DIAGNOSIS OF GENUS}

Genus solely marine.

Phycomata $14-230 \mu \mathrm{m}$ in diameter when mature, greenish yellow to golden brown, sphaeroidal, subglobose or ellipsoidal, non-cellular, with a double wall, inner delicate and of a pectic nature, outer tough and of unknown composition staining yellow with iodine. Outer wall smooth, hebetate, papillose and/or poroid, bearing alae (wings) protruding at right angles from the wall surface, sometimes originating from a distinct alaband (wing band) in species with a single equatorial ala; alae smooth or maculate, staining paler yellow with iodine than outer wall, delimiting surface of outer wall into two, or into triangular, quadrangular or polygonal areas. Mature-sized phycoma containing a single nucleus at first, small lipid globules and numerous discoidal plastids possessing chlorophyll $a$ and $b$, each plastid containing a pyrenoid with a surrounding starch shell, staining purplish red with iodine.

Release of inner wall and contents through slit in outer wall; contents usually showing early stages of fission; fission of contents continuing inside inner wall until wall filled with flagellated cells; inner wall then bursting and liberating flagellated cells.

Cells of motile phase, delicate, $4^{-10} \mu \mathrm{m}$ in size. Body variable in shape, circular, elliptical or oval in morphological anterior or posterior view, showing various degrees of compression, at the extreme patelliform; slightly to strongly convex on one side (morphological posterior), flat or concave on the other (morphological anterior).

Flagella four, 3-10 times body diameter in length, inserted eccentrically on flat or concave surface; bearing one or two types of hairs and a two-layered covering of scales: under layer of small, five-lobed plates about $0.05 \mu \mathrm{m}$ across their widest part, outer layer of roughly oval-oblong plates about $0.3 \mu \mathrm{m}$ in length by $0.2 \mu \mathrm{m}$ in breadth, bearing an adnate spine arising centrally on the outer side and protruding about $0.05 \mu \mathrm{m}$ beyond anterior margin.

Body scale covering three-layered; innermost layer of small squarish four-lobed plates about $0.05 \mu \mathrm{m}$ across their widest part; outer layers of roughly octagonal and nonagonal plates, differing usually on the two sides, from $0.25-0.35$ (occasionally 0.45 ) $\mu \mathrm{m}$ in diameter.

Plastid saucer-shaped, parietal, greenish yellow to golden brown, lying against convex surface of body, containing a pyrenoid with a surrounding starch shell staining purplish red with iodine. Nucleus lying eccentrically in body. Stigma absent. Lipid body and muciferous organelles usually present.

Fission in motile phase, daughter-cells usually of equal size. No evidence of sexuality in genus.

Distribution: Arctic Ocean, North and South Atlantic Oceans, North Sea, Mediterranean Sea, Red Sea, Indian Ocean, North East Pacific Ocean (R. Jowett, unpublished). 


\section{THE PHYCOMA PHASE}

Since phycomata flatten out under pressure, they should be examined at first without a cover-slip so that the arrangement of the alae and proportions of their width to body diameter may be noted (cf. Pls. VID, E, VIIL, M). The finer details of the outer wall structure can be studied equally well on preserved as on living material. Empty ones, if available, are the most rewarding to study but these details can be obtained from a full phycoma by studying, under high magnification, the parts of the wall lying over the lipid globules (Pl. IJ). If the phycoma is then squashed gently until it bursts and expels its contents, the structure and arrangement of pores in the outer wall can be seen. Treatment with $\mathrm{KI}_{3}$ (iodine in potassium iodide) tends to show up pores more clearly but unfortunately in some species this treatment makes the wall brittle and likely to shatter under slight pressure.

A phycoma belonging to the genus Pterosperma should show the following:

(a) An ala or alae arising at right angles from the external face of the outer wall ( $\mathrm{Pl}$. $\mathrm{IA}_{\mathrm{A}} \mathrm{H}$ ); both outer wall and alae should become yellow after treatment with $\mathrm{KI}_{3}$, alae paler than body wall.

(b) An inner wall (Pl. IIIF, G, J) which becomes pink after treatment with ruthenium red, indicating its pectic nature; inner wall takes up stain both when inside outer wall and after its release from it.

(c) A single large nucleus until maturity is reached.

(d) Numerous small discoid plastids (Pl. II K-M), each containing a pyrenoid with a surrounding starch shell which becomes purplish crimson to reddish brown after treatment with $\mathrm{KI}_{3}$ (Pl. XIIG).

(e) Numerous lipid globules (Pls. IK, II A-N) which, when free from the phycoma inner wall, become orange-red to bright red when treated with alcoholic sudan III or IV.

For the identification of a Pterosperma species the following data concerning the phycoma outer wall are required:

(i) Shape and size of the phycoma body.

(ii) Surface appearance of body, whether smooth or papillate and whether or not there are zones present differing in appearance (cf. Pl. VII G, H).

(iii) Depth and arrangement of ala or alae; the variation in alae arrangement within an apparent species (cf. p. 251 and Pl. VA-F, K, L).

(iv) Surface appearance of ala or alae.

(v) In species with a single equatorial ala presence or absence of an alaband; if present, width and characteristics of both structures. (Pls. VIIJ, XIII A-J).

(vi) Presence or absence of alaband pores (Pls. VIIH, XIc).

(vii) Presence or absence of pores in wall other than alaband pores; if present, their arrangement in wall and details of their structure, which may be complex (Pls. IF, L, VIG, IXD-F). 


\section{Development of the phycoma phase}

The phycomata of seven species of Pterosperma have been produced and grown in culture from the motile cells liberated from phycomata obtained from the sea. The phycomata of some species have been grown to maturity with the subsequent release of the second generation of motile cells and in one species, $P$. nationalis Lohm., a second generation of mature phycomata has been grown from these. In all members of the Pterospermataceae studied, immediately after the motile cell has cast its flagella and transformed into the phycoma by producing walls and alae (Pl. II A, B), an extremely rapid increase in its volume and lipid content must take place since other body contents, for example, the plastids, appear sparse at this stage (P1. IID). In this characteristic young stage (Pl. II A-D) the single plastid of the motile cell has divided up into numerous small round to oval plate-shaped plastids which now surround usually one large central lipid globule.

Some of the stages described by Schiller (cf. 1925, p. 85, fig. Sb) as stages of Halosphaera are almost certainly young phycomata of members of the Pterospermataceae since they possess a large central lipid globule; the presence of a lipid globule is a useful character for separating young Pterosperma and Pachysphaera phycomata from very young phycomata of Halosphaera species.

From data on phycomata grown in culture (cf. p. 257) growth of the phycoma outer wall in both size and thickness undoubtedly continues, after the rapid initial size increase, until the phycoma reaches maturity. The fine structure of the outer wall of Pterosperma has not yet been investigated nor as already stated is its composition known but the wall structure of Halosphaera (Jux, 1969b) and Pachysphaera (Jux, 1969a) are known and Professor R. D. Preston, F.R.S. (personal communication), believed the composition of the Halosphaera wall to be related to sporopollenin. Jux suggests that the pilae in the Halosphaera wall and the radial canals in the Pachysphaera wall play an important part in transport of materials for wall growth and for osmotic exchanges. $\mathrm{He}$ demonstrated the presence of growth lamellae in the outer wall, suggesting that the thickening and widening of the wall takes place from the inside outwards. As the inner wall was not always visible in sections Jux $(1969 a, b)$ believed that it might be formed only as the phycoma approached its mature size. We have, however, demonstrated its presence in young phycomata (Pl. IIG).

As the phycoma size increases, the contents, except the nucleus, continue to divide (P1. II). The peripherally lying plastids show fission stages with two or four pyrenoids, each pyrenoid with its starch shell and the large central lipid mass cuts off globules from the peripheral region $(\mathrm{Pl}$. II H, J). This process continues until the centre of the phycoma is full of small lipid globules surrounded by plastids (Pl. IIE, F). Maturity is reached when all the lipid material has divided up into very small globules of about the same size and each of the numerous plastids contains a single pyrenoid (Pl. IIN). What controls the mature size of a phycoma is unknown but phycomata of some species taken from the same sample can show an extremely wide range of size at maturity although the motile cells, produced by the different sized phycomata, are identical in size and structure. 
The time taken for phycomata to reach maturity varies considerably between and within species. In the case of freshly collected phycomata, the longest period recorded for this was two lunar cycles after collection, that is about seven weeks. These had been collected between moon phases in late October. The longest maturation period recorded for phycomata in culture was about three and a half months following the changeover from motile to phycoma phase while the shortest was 14 days including the changeover and the liberation of the next generation of motile cells.

\section{Liberation of the motile phase}

Although liberation of motile cells has been recorded in 17 species of Pterosperma and these have been studied, it has only been possible to obtain formalin preserved phycomata of the type species, $P$. rotondum. We have accumulated abundant evidence that release occurs over a period of from 5 to 6 days, 2-3 days either side of the new or full moon. The lunar rhythm is frequently retained for a period (up to 2 lunar cycles) after phycomata have been placed under culture conditions. For example, in $P$. marginatum Gaarder young to mature phycomata were isolated into culture from samples collected on 25 Jan. 1967. Release from them was recorded on the following dates:

$$
\begin{array}{ll}
\text { 27 Jan. } 1967 & \text { [full moon 26 Jan. 1967] } \\
\text { 21 Feb. 1967 } & \text { [full moon 24 Feb. 1967] } \\
10 \text { Mar. 1967 } & \text { [new moon 11 Mar. 1967] }
\end{array}
$$

Phycomata tend to release their contents more readily when in mass or mixed culture rather than when growing singly. A phycoma about to release its contents can usually be detected since its inner wall has thickened considerably, showing as a clear peripheral layer inside the outer wall (Pl. IIF). The nucleus and the phycoma content as a whole have started dividing to form 2,4 or occasionally 8 uninucleate masses (Pl. IIN). Possibly owing to pressure caused by the increase in thickness of the inner wall, the outer wall bursts at this stage (Pl. III A-H) releasing the inner wall, with its contents, through a small slit, the slit almost certainly occurring at a predestined position in the wall, the release suture. The suture usually appears in the same position in the outer wall in individuals of a particular species (cf. Pls. IIIG, H, VIID). Although the presence of an incipient suture in Pterosperma has not yet been confirmed by sections examined under the electron microscope, Jux (1969b, taf. 27, figs. 1-5, and taf. 29, figs. 9-11) has demonstrated clearly the presence of an incipient suture in the outer wall of immature phycomata of Halosphaera russellii Parke but only in mature phycomata of Pachysphaera marshalliae Parke. In both these species the 'fault' zone does not pass completely through the outer wall, it stops beneath the boundary layer which is reinforced during growth by the incorporation of electron dense particles which presumably prevent the bursting of the wall at the weakened zone.

Immediately after release (Pl. IIIA) the phycoma inner wall enlarges to twice the diameter of the outer wall (PI. IIIB-G). At the two and four nucleate stage the masses remain connected together (Pl. IIIC-E), but after the third nuclear division, the eight masses, each with numerous plastids and lipid globules, develop flagella, separate and become motile inside the inner wall (Pl. IIIF). Fission of these moving masses, usually 
into four (Pls. III J-L, N, VIIN), continues until each motile cell contains a single lipid body. Early stages may contain 2, 4, 8 or 16 lipid globules (Pl. IIIL). As fission continues, the inner wall increases in diameter and decreases in thickness until, full of motile cells, it becomes extremely fragile and difficult to isolate without it bursting (Pl. III M-Q). It can measure up to $800 \mu \mathrm{m}$ in diameter, about 16 times the diameter of the outer wall from which it was released (Pl. III M). Eventually the inner wall bursts to free the motile cells, the whole process having taken usually from 2 to 4 days, longer in February and early March than in late March and April.

\section{THE MOTILE PHASE}

As was found in the genus Pachysphaera (Parke, 1966), the motile phase of the genus Pterosperma is difficult to maintain in culture for unlimited periods although two species have been kept in culture for quite long periods. $P$. nationalis since 4 Mar. 1963 and $P$. polygonum Ostenf. since 21 Mar. 1966. The most successful medium for $P$. nationalis is $\frac{1}{4}$-strength Erd-Schreiber while for $P$. polygonum a really successful medium has not been found, it grows slowly in a mixture of $\frac{1}{4}$-strength Erd-Schreiber, Miquel-Allen Medium and $\mathrm{ASP}_{2}$ in proportions 1:1:1. Motile cells of most of the species investigated have been grown in culture for short periods but unfortunately they die off after a few months in culture. They have been recorded from water samples taken off the S.W. coast of England, and are known to occur as far west as the edge of the continental shelf quite commonly from March to November but less so from December to February.

The motile cells from different Pterosperma species show quite considerable differences in innate 'toughness'. Some, for example $P$. nationalis, are comparatively robust, swimming and moving apparently quite normally for long periods when observed under the optical microscope, while others appear extremely delicate. The latter stop swimming and discard their flagella almost the instant they are placed under the optical microscope, in fact in some species, for example $P$. polygonum. it is difficult to record body shape and size or characteristics of swimming actions before the cells collapse and disintegrate.

Release of motile cells from the phycoma has been witnessed in 26 species belonging to the Pterospermataceae but, as stated earlier, not from the type species of the genus Pterosperma. Although a detailed study of the motile cells from each species has been made it must be admitted at the outset that it has been impossible to distinguish a species in its motile phase since the motile cells from different species are all so very similar in size and appearance most of them showing no distinctive specific characters, except for slight variations in scale pattern at the ultrastructural level.

The general characters of the cells of the motile phase (Pl. IV A-C) have already been given in the revised diagnosis of the genus (p. 243); further details are given under the species headings. The general characters of the flagellar and body scale-coverings are detailed below.

\section{Characters of the scale covering}

Optimistically, it was hoped when this work began that the scale characters or other features of the Pterosperma and Pachysphaera motile cells would be quite distinctive. 
This hope has not materialized however: some Pterosperma species produce outer body scales possessing characters more usually noted for Pachysphaera species while others, apparently Pachysphaera species, as they lacked alae, produce body scales more characteristic of the genus Pterosperma. Body scale types therefore are no indication of genus if the separation of the two genera is to be made on the presence or absence of an ala or alae on the outer wall of the phycoma.

As in a number of prasinophycean genera already studied (Manton \& Parke, 1960; Manton et al. 1963; Parke \& Rayns, 1964; Swale \& Belcher, 1968; Swale, 1973) the flagella and body of the motile cell, when seen under the transmission electron microscope (TEM) are found to be covered by a coherent periplast composed of scales, interspersed on the flagella with hairs. The resemblance between the scale characters in Pterosperma and those already described (Manton et al. 1963) in Pyramimonas and Pyramimonas stages of Halosphaera is so close that direct phyletic affinity between these genera seems indisputable, at least within the concept of a common class (Parke \& Green in Parke \& Dixon, 1976).

\section{The flagellar scales (Pl. IV L)}

The outer layer scales are roughly oval-oblong plates $0.31 \times 0.19$ to $0.34 \times 0.21 \mu \mathrm{m}$ in size. Their basic construction is similar to that of the body plate scales. When in position on the flagellum the spines of successive scales are strictly aligned as in Halosphaera giving one the impression that there are regular longitudinal striations along the length of an intact flagellum. When undisturbed the distal edge of each scale overlaps the proximal edge of the adjacent scale (PI. XIE). The central adnate spine on the outer surface of the scale runs down two-thirds of the length of the scale extending beyond the scale margin at the distal end for $0.04-0.06 \mu \mathrm{m}$. At its proximal end, the spine is connected to 3 struts which pass outwards to the margin of the scale. The inner surface of these scales shows patterning somewhat resembling that of a spider's web but bears no adnate spine.

The under layer scales measure $0.04-0.05 \mu \mathrm{m}$ across their widest part and appear to be composed of five lobes surrounding a central hub (Pl. IVL). They are closely packed in rows and are apparently embedded in some kind of cementing material. Short fragile caducous hairs are present on the flagella (Pl. IVL). In addition to these there are in some species larger hairs, with a characteristic cross segmental patterning, occurring near the flagellar bases (Pl. XIVA, B).

\section{The body scales (Pls. IV, VIII)}

The outer-layer scales are roughly octagonal or nonagonal plates built up of a number of 'radii' connected together by striae. There are apparently 4 'radii' partially subdivided to form 8 or 9 'sectors'. These are not true sectors but in order to simplify general scale descriptions we will refer to the scales as having 8 or 9 ' radii'. The following scale types have been recorded from the two outer scale layers on the body.

Scale type 1 - very large scales (Pl. VIIIF, L), $0.44 \mu \mathrm{m}$ in diameter, have been recorded from only one species, $P$. moebii. The scale is composed of 9 'radii' with up to 10 rings of striae evenly spaced or in groups of $2-4$. The difference between the 
two faces is very slight. Both bear a small central hub formed at the junction of the 'radii'.

Scale type 2 - large scalloped scales (Pl. VIIIC, D), $0.30-0.38 \mu \mathrm{m}$ in diameter, have been recorded for all the species studied. The scale is composed of 9 'radii' with 4-8 rings of striae evenly spaced or, more often, in groups of up to 5 , the outermost striae (in 1-5, usually 2-3 rings) being curved outwards to give a scalloped appearance to the margin of the scale. The difference between the two faces is very slight. Both or neither bear a small central hub formed at the junction of the 'radii'.

Scale type 3 - large pointed scales (Pl. VIIIG, H), $0.27-0.33 \mu$ m diameter, have been recorded for some species. The scale is composed of 8 rather twisted 'radii' with 5 or 6 rings of striae evenly spaced or in groups of 2 or 3 . The outermost striae (only one ring) are curved sharply inwards. Four 'radii' are more prominent on one face of the scale. The other face bears a distinct central hub formed at the junction of the radii.

Scale type $4-$ medium scale (Pl. VIIIJ, $\mathrm{K}$ ), $0.24-0.28 \mu \mathrm{m}$ in diameter, have been recorded for all the species studied. These scales do show slight specific variations but in all species they are composed of 8 'radii' with 5 rings of striae evenly spaced. The outermost striae (only 1 ring) are either not curved or curved inwards to varying degrees. Four 'radii' may or may not be more prominent on one face of the scale. Both faces, either face, or neither face may bear a small or large central hub formed at the junction of the 'radii'.

The under-layer scales measure $0.04-0.05 \mu \mathrm{m}$ across their widest part and appear to be composed of 4 lobes surrounding a central hub. They are closely packed in rows and

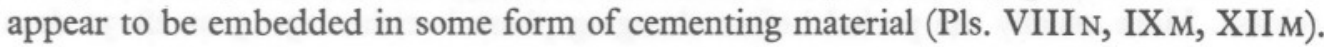

\section{Fission in the motile phase}

Asexual reproduction occurs by fission of the motile cell into two daughter-cells usually of equal size (Pl. IV H-K). Frequently the new flagella do not develop until after the daughter-cells have separated and therefore it is not unusual to find motile cells with only 2 flagella. Cells showing double fission, with four plastids and 8 flagella, have been observed occasionally in very rapidly growing cultures of $P$. nationalis. Early fission stages show a broadening of the body with the consequent separation of the flagella into 2 pairs and the fission of the pyrenoid with its surrounding starch shell (PI. IVD, E). The plastid then divides and four daughter-flagella may or may not develop at this stage between the 2 pairs of parent flagella (Pl. IVE, H). It is not yet certain whether the lipid globule divides during cell fission or whether a new one arises. The nucleus divides last and then fission of the actual cell body begins at the flagella pole and then, but more slowly, at the opposite end of the body (Pl. IVH-K).

\section{Mode of swimming}

Motile cells of all Pterosperma species studied, even those undergoing fission (Pl. IVc, F, H), display the same characteristic swimming action by which they can instantly be recognized as pterospermatacean forms (see Parke, 1966, p. 559.for Pachysphaera). When swimming the body appears saucer-shaped or bean-shaped in side view; the morphological anterior bearing the flagella is concave and directed backwards while the 
morphological posterior is convex and directed forwards. Swimming is rapid with quick rotation of the body, the flagella always lying behind showing a characteristic curved shape (Pl. IVC). Slight variations do occur in swimming behaviour between species, for instance $P$. marginatum and $P$. polygonum have their flagella so close together behind the body that when a cell rotates rapidly it is difficult to count the number present although the characteristic attitude for the family is still held. During slower movement the flagella lie close together and undulate.

Between bouts of rapid swimming the cells may frequently be observed attached to the slide by the distal ends of their flagella, the unattached parts and the body exhibiting a dancing, dithering or vibrating movement which is also quite characteristic (Pl. IVG) Motile cells frequently glide quite rapidly without rotating and, in between bursts of rapid swimming or gliding, become stationary for a short period and then start to rotate quickly with the flagella sweeping around at the same time.

\section{Change from motile to phycoma phase}

What actually triggers off the phase change is unknown as in some cases motiles originating from a single phycoma will transform into phycomata while others from the same parent phycoma and under identical conditions will remain as motile cells. In addition, the motile cells originating from a single phycoma that do change phase do not always change over on the same day. Our records show that the return to the phycoma phase may occur over a period of at least 4 days over the lunar period. The motiles can also return to the phycoma phase occasionally very rapidly, only 3-4 days after their release. More usually the period before changing phase is either $13-15$ or $28-30$ days after release but it can be longer. Culture studies do suggest that in general the return from the motile to the phycoma phase is more rapid from April to June than during the period from November to March, although periods of from 4 to 12 days from release of motiles to their return to phycomata were recorded for late November and early March.

The genus Pterosperma therefore shows a similar pattern of behaviour to the genus Halosphaera (Parke \& Hartog-Adams, 1965; Parke, unpublished data for $H$. parkeae Boalch et Mommaerts) and also to that of the genus Pachysphaera (Parke \& Jowett, unpublished). No evidence has been obtained that sexuality is involved in the production of phycomata from motile cells of the genus Pterosperma, and the allied genera Pachysphaera and Halosphaera.

The motile cell discards its four flagella, rounds off and secretes the phycoma wall. If a high proportion of motile cells are changing to the phycoma phase in culture the bottom of the flask becomes covered with a thick layer of discarded flagella. When motile cells are about to change to phycomata the muciferous organelles, situated peripherally in the body, become more numerous and more obvious. As was suggested for Halosphaera (Parke \& Hartog-Adams, 1965) these organelles may be involved in the production of the phycoma wall since they are still present in cells just forming walls but disappear as soon as the walls and alae are clearly distinguishable.

In the species studied, the newly formed phycomata are very small measuring only from 8 to $27 \mu \mathrm{m}$ including ala or alae, depending on the species. The earliest observed stage is a rounded-off uninucleate cell which has cast its flagella but which still retains 
its scale covering and contains numerous muciferous organelles and usually a single lipid globule. Whether the scale covering to the body persists, is cast or re-absorbed is not yet known but the cell, after losing motility, becomes surrounded by a distinct layer of clear material which apparently becomes the phycoma wall (cf. also Schiller (1925), p. 82, text-fig. Q, $a-d$ - probably pterospermatacean stages not halosphaeracean). While the walls are forming, the alae develop on the outside. The young phycoma now contains one to four plastids, a single large nucleus, a lipid globule and frequently groups of muciferous organelles.

At this early stage the outer wall pores cannot be resolved; not even in $P$. marginatum could the large pores present in the older stages be detected. Pores must therefore develop later, during the period of very rapid increase in size which has already been discussed on page 245 .

In some species bearing an equatorial ala, e.g. $P$. citriforme sp.nov., the alaband is clearly visible in early stages, which measure $10 \times 8 \mu \mathrm{m}$, but in other species, e.g. $P$. moebii, the alaband could not be resolved in a newly formed young phycoma with a total diameter of $27 \mu \mathrm{m}$, the body measuring $15 \mu \mathrm{m}$ in diameter. It is not possible at present to give an accurate time for the process of changeover from motile to phycoma. However, from observations made on cultures we know it can occur within $4 \mathrm{~h}$.

\section{VALIDITY OF CRITERIA FOR GENERIC AND SPECIFIC SEPARATION}

GENERIC CHARACTERS

In 1904 Lohmann, although agreeing that the generic name Pterosperma must be maintained, decided to divide up the species already described by that date, into four genera, retaining the name Pterosperma for the forms bearing a single equatorial ala. $\mathrm{He}$ also retained, with emendation, Jørgensen's name Pterosphaera for forms bearing many intersecting alae defining quadrangular or polygonal fields and erected two new genera, Pterocystis for forms bearing a few intersecting alae defining triangular fields and Pterococcus for forms bearing alae that are T shaped in cross-section and define polygonal fields. Bourrelly (1957), in his classic work on the Chrysophyceae, followed Lohmann in splitting up the genus Pterosperma and designated type species for the four genera.

Ostenfeld (1913), however, was not in agreement with the splitting up of the genus on the basis of ala arrangement alone. Our in vivo studies have produced proof that the pattern of ala arrangement is not a stable character. For instance, using $P$. nationalis as an example (Table 1), in samples examined from the sea we found phycomata with the same general appearance and pore structure, apparently all the same species, but with variable arrangements of alae. Phycomata outer walls (Pl. VA-D) were found with their alae arranged to show:

(1) 4 triangular fields recorded as 'all 3 's';

(2) 6 quadrangular fields recorded as 'all 4 's';

(3) 2 triangular and 3 quadrangular fields recorded as ' 3 's and 4's';

(4) 5 quadrangular and 2 pentagonal fields recorded as ' 4 's and 5 's'. 
The commonest occurring forms off the SW coast of Britain and off the continental shelf were (2) and (3), whereas in the samples collected for us from the Arctic by Dr N. Reynolds (4) occurred most commonly, (2) fairly commonly, (3) rarely and (1) was not recorded. The question was therefore: Did the different types of ala arrangement indicate different species? Since only growth studies could give the answer the release of the motile phase was obtained from two separate washed phycomata, collected from our area, one type (2) and the other type (3). The motile cells from both phycomata, still kept separately, changed back to the phycoma phase and then grew to maturity. Three hundred daughter-phycomata from each series were then studied for ala arrangement. It was found that the percentages of the different forms from each phycoma agreed with those of the different forms occurring naturally in the sea from the same region (Table 1). It would be interesting to know if Arctic material would, in culture, produce a much higher percentage of phycomata of type ' 4 's and 5 's'.

Table 1. Percentages of various alae arrangements recorded as occurring in the progeny from two separate mature phycomata of Pterosperma nationalis

\begin{tabular}{|c|c|c|c|c|}
\hline \multirow[b]{2}{*}{ Parent phycoma } & \multicolumn{4}{|c|}{ Daughter-phycomata } \\
\hline & $\begin{array}{l}\text { (1) Pl. VD } \\
\text { 'all 3's' } \\
\text { (+ irregular) }\end{array}$ & $\begin{array}{l}\text { (2) Pl. V B } \\
\text { 'all 4's' }\end{array}$ & $\begin{array}{l}\text { (3) Pl. V c } \\
\text { '3's and 4's' }\end{array}$ & $\begin{array}{l}\text { (4) Pl. VA } \\
\text { '4's and 5's' }\end{array}$ \\
\hline $\begin{array}{l}\text { '3's and } 4 \text { 's' } \\
\text { 'all } 4 \text { 's' }\end{array}$ & $\begin{array}{l}17 \% \\
13 \%\end{array}$ & $\begin{array}{l}43 \% \\
48 \%\end{array}$ & $\begin{array}{l}23 \% \\
22 \%\end{array}$ & $\begin{array}{l}17 \% \\
17 \%\end{array}$ \\
\hline
\end{tabular}

Other species grown in culture, for instance $P$. marginatum and $P$. polygonum, also show variation in number of sides to the polygons. Although we have not grown daughterphycomata of $P$. cuboides Gaarder and $P$. vanhoeffenii (Jørg.) Ostenf. in large numbers we have found in naturally occurring individuals similar variation (Pl. VE, F, K, L). P. nationalis from our area has never produced phycomata either in the sea or under culture conditions with the alae/body proportions characteristic for $P$. cuboides or $P$. vanhoeffenii from our area. In addition the scale structure on the motile cells obtained from phycomata with different ala arrangement (e.g. P. vanhoeffenii 'all 3 's' and ' 3 's and 4's') have been shown to be identical. The splitting of the genus Pterosperma by Lohmann on the basis of ala arrangement is therefore not tenable.

During the early part of this work we considered the possibility of splitting the genus into two, retaining in the genus Pterosperma only those species with a single equatorial ala arising from an alaband, since those we had studied all had a distinct alaband. Later, however, we found mature phycomata of two new distinct species, each with a single equatorial ala but no evidence whatsoever of the presence of an alaband and therefore our suggested splitting of the genus could not be adopted. We have therefore retained in the genus Pterosperma all the forms bearing an ala or alae on the outer wall of the phycoma. 


\section{SPECIFIC CHARACTERS}

Earlier workers used some of the following characters as criteria for specific separation:

- phycoma appearance and size;

- width and appearance of ala or alae;

- relative body size to total diameter;

- arrangement of alae on body;

- presence or absence of pores;

- appearance of alaband if present.

The validity of the use of the above characters for specific identification is discussed below in connexion with the criteria we believe stable and therefore valid for this purpose. These concern the microscopic structure of the outer wall of the phycoma as detailed on page 244 and summarized below:

- appearance of the outer surface of wall and of ala or alae;

- presence or absence of pores other than alaband pores, if present their structure and arrangement in the wall.

- presence or absence of an alaband, if developed whether protruding or insignificant;

- presence or absence of alaband pores, if present their arrangement in the outer wall.

Certain other phycoma characters, though slightly less stable, must also be considered for specific identification. For instance, the relative proportions of the phycoma body size to ala width or alae depth are of importance particularly among the species bearing an equatorial ala. The mean ratio of total phycoma body to total diameter may vary considerably between some species, for example the ratio is $1: 1 \cdot 1$ in $P$. citriforme sp.nov. and 1:3.2 in P. eurypteron sp.nov. These proportions, when taken in conjunction with the outer wall features, are decisive for species identification. Slight variation of this ratio has been recorded, particularly in species bearing alae defining polygonal fields, but this feature is still valuable for specific identification when supplemented with apparently stable characters. As mentioned earlier, in order to obtain the correct relative proportions of body diameter to ala, width measurements of phycomata should be made with phycomata not under pressure.

In all species, other than those bearing a single equatorial ala, the general appearance of a phycoma due to the relative depth, number and arrangement of alae can be helpful in the preliminary stages for quick identification down to a group of species. Again, as above, specific identification requires supplementation of these data. The actual body size of a mature phycoma and the depth of the alae alone are valueless for specific identification since, as mentioned earlier, the range of size of mature phycomata within a species is exceptionally large, for example P. moebii 47 (20) $\mu \mathrm{m}$ to $230(110) \mu \mathrm{m}(\mathrm{Pl}$. VG, $\mathrm{H})$ and $P$. cuboides (Pl. VJ, L). Very small mature phycomata are not infrequently collected (cf. Halosphaera parkeae f. minuta, Boalch \& Mommaerts, 1969), more commonly from November to February, along with the usual larger phycomata. The wall structure of all sizes of phycomata is identical; also the motile cells liberated are identical in size, structure and scale patterning. These very small mature phycomata have been recorded 
for a number of the species studied and in fact we obtained motile cells from phycomata which had reached maturity at these small sizes in culture. At present we have no explanation to offer as to why these 'dwarf' forms should occur.

The more important facts ascertained or verified by us for the seven species are summarized in Table 3 on page 266 . A key is also provided on page 269 for the determination of the species discussed in this paper.

\section{DIAGNOSES AND DESCRIPTIONS OF SPECIES}

Detailed information on seven species of Pterosperma, four new to science, is included in the present paper. Each bears a single equatorial ala on the outer wall of the phycoma. The remaining Pterosperma species, in which the phycoma outer wall bears intersecting alae defining triangular, quadrangular and polygonal fields, will be dealt with in a later paper. The data presented here on the distribution of Pterosperma species have been obtained mainly from the limited sea area off the SW coast of Britain. This area, for convenience has been delimited into three regions, coastal, inshore and offshore, the boundaries for each region being depicted in Fig. 2.

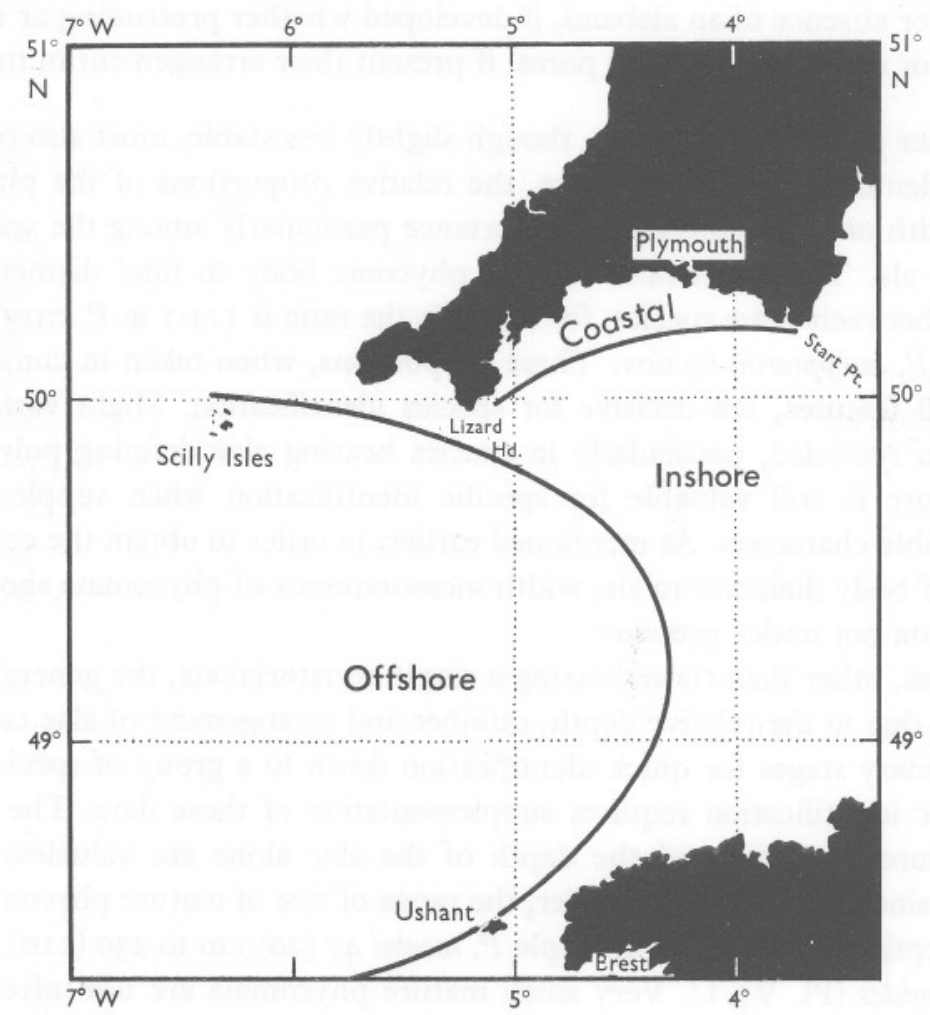

Fig. 2. The sea area, delimited into three regions (coastal, inshore and offshore), off the SW coast of Britain, from which the distribution of Pterosperma species has been regularly recorded. 


\section{Pterosperma rotondum Pouchet - type species}

\section{Original description}

(Fig. 1, Plate VIA-K)

The species was first distinguished by Pouchet in 1893 . He recorded it from plankton samples collected from the Dyrefjord, Iceland $\left(65^{\circ} 50^{\prime} \mathrm{N}, 23^{\circ} 40^{\prime} \mathrm{W}\right)$ in July-August 1891. Although Pouchet gave a short diagnosis (see p. 241) and an illustration (Fig. 1) for this species he gave no indication of its size. It has not been recorded with certainty since the original finding. The Pterosperma we believe to be Pouchet's species, P. rotondum, has been isolated (Pl. VI) from fine tow-net samples collected for us by Dr N. Reynolds in August-September 1968 from stations between long. $54^{\circ} 50^{\prime} \mathrm{N}$ and $59^{\circ}$ $00^{\prime} \mathrm{N}$, lat. $02^{\circ} 00^{\prime} \mathrm{E}$ and $00^{\circ} 58^{\prime} \mathrm{W}$ at the surface (Ernest Holt Cruise $7 / 1968$ ).

Examination of the phycomata of this small delicate species (PI. VIA, B) while under cover-slip pressure, has shown that they behave as Pouchet's material behaved, presumably also under cover-slip pressure. The body inevitably flattens out more than the ala thus reproducing one of the effects illustrated by Pouchet (cf. Pl. VID, E). Another effect (Fig. 1 and Pouchet, 1893, fig. 18 A) can be reproduced when some of the lipid material has, under pressure, oozed out through the alaband pores and into the ala (Pl. VIF). It is not as readily reproducible when using phycomata of most other Pterosperma species.

We feel justified therefore in attaching Pouchet's name, $P$. rotondum, to this organism and in selecting this one of Pouchet's elements as a satisfactory type to uphold the retention of the genus name Pterosperma which is now in general usage, rather than allowing it to be rejected in favour of Pterosphaera Jørgensen. Bourrelly (1957), as mentioned earlier (p. 242), designated P. rotondum as the type species of what is now considered to be one section (equatorial ala) of the genus Pterosperma. We now designate $P$. rotondum Pouchet as the type species of the whole genus as now delimited, that is including the genera Pterocystis Lohmann and Pterosphaera Jørgensen as circumscribed by Lohmann in 1904 .

Lectotype: Pouchet, 1893 , p. 178, fig. 18 A.

\section{Synonymy}

Trochiscia rotunda (Pouchet) Lemmermann, 1903, p. 349.

\section{Description of species}

Phycoma with single, equatorial, undulate, not conspicuously maculate ala, (47) $55-87$ (94) $\mu \mathrm{m}$ total diameter; ala width about half body diameter, usually showing either 20-22 plicae tapering from body towards ala margin or 10-11 undulations (P1. VIв, C). Body sphaeroidal, occasionally subglobose, (20) $25-40$ (44) $\mu \mathrm{m}$ in diameter; mean ratio of body diameter to total diameter $1: 2 \cdot 2$, range: $1 \cdot 9-2 \cdot 4$; under pressure ratio $1: 1 \cdot 4$.

Outer body wall with equatorial, inconspicuous, narrow, smooth, alaband, $1 \cdot 5-2 \cdot 0 \mu \mathrm{m}$ wide, with slightly raised scabrellous margins $(\mathrm{Pl}$. VIH, J) and one ring of distinct alaband pores, $2-3 / \mathrm{m}$ apart, on either side of alaband lying in outer wall close but ex- 
ternally to each alaband margin (Pl. VIJ). Ala insertion on alaband central but showing shallow undulations (Pl. VIH). On either side of alaband phycoma wall coarsely and irregularly papillose (Pl. VIG, J, K), lacking pores other than alaband pores, forming broad band covering $0.25-0.3$ of each hemisphere; remainder of wall much more finely papillose forming deep caps at both poles and containing spaced, clearly defined pores (PI. VIG). Papillose region either side of alaband in P. rotondum much more coarsely and irregularly papillose than in $P$. moebii. Band of $P$. moebii has appearance of being evenly stippled with dots of the same size (Pl. VIIH).

Contents of phycoma body as described for genus. Motile phase not studied as preserved material only available for examination.

Distribution - as the phycoma phase

Dyrefjord, Iceland, July-August 1891 (Pouchet, 1893); Norwegian Sea, AugustSeptember, 1968.

\section{Pterosperma moebii (Jørgensen) Ostenfeld}

(Plates VIIA-N, VIIIA-N)

\section{Original description}

The species now delimited as Pterosperma moebii was first distinguished as a 'Welliger Statoblast' by Hensen in 1887 when he found, in material from the Skagerak, 1137 individuals under $1 \mathrm{~m}^{2}$. He illustrated one in polar view in his fig. 28 , taf. Iv, its equatorial ala showing 18 undulations, and recorded its size as $80 \mu \mathrm{m}$ body diameter and 190 $\mu \mathrm{m}$ total diameter, these proportions being in agreement with those for the species $P$. moebii as now delimited. His illustration (fig. 29, taf. Iv) of the side view, if accurate, is probably of a different species since the body is spherical, with a greater ala/body ratio than he has indicated in fig. 28. Fig. 29 of Hensen should therefore be omitted from references to $P$. moebii particularly as Hensen himself states that he found a second type similar to the first wavy statoblast only without granulations on the surface. His second type and his fig. 29 can be referred almost certainly to the new species $P$. eurypteron (see p. 259).

Jørgensen in 1900 described and named Hensen's 'Welliger Statoblast', as Pterosphaera moebii, but the size given (for one phycoma only) should be omitted from references to $P$. moebii as the ala/body ratio is that of the new species Pterosperma eurypteron. Cleve, later in the same year, described the same entity independently as Cysta limbata. He referred also to Hensen's description and figures of his 'Welliger Statoblast'. Ostenfeld (in Ostenfeld \& Schmidt, 1902) transferred Jørgensen's species to the genus Pterosperma Pouchet (1893).

It is just possible however that the illustration of the second species described and named $P$. ovatum by Pouchet $(1893$, p. 178 , fig. 18 B) could have been of a P. moebii phycoma with a torn ala, the phycoma having been rolled over under cover-slip pressure onto side view (compare Fig. 1 B with Pl. VIIE). As this is uncertain and as dinophycean affinities have already been suggested for $P$. ovatum it is more prudent to retain the specific name $P$. moebii for this entity.

Lectotype: Hensen, 1887, p. 67, taf. Iv, fig. 28. 


\section{Synonymy}

'Welliger Statoblast' Hensen (1887, p. 67, taf. Iv, fig. 28)

?Pterosperma ovatum Pouchet (1893, p. 178, fig. 18B)

Pterosphaera Möbii Jørgensen (1900, p. 48, excl. magn.)

Cysta limbata Cleve (1900, p. 18)

Pterosperma möbii (Jørgensen) Ostenfeld in Ostenfeld et Schmidt (1902, p. 151)

Trochiscia moebiusii (Jørgensen) Lemmermann (1903, p. 349)

Pterosperma atlanticum Lohmann (1904, p. 43, taf. vI, figs. 1, 3, 10)

Pterosperma Saturnus Meunier (1910, p. 90, pl. v, figs. 23, 24)

Cysta moebii (Jørgensen) Loeblich et Loeblich (1960, p. 537)

\section{Description of species}

Phycoma with single, equatorial, undulate, conspicuously maculate ala, (47) 120-200 (230) $\mu \mathrm{m}$ total diameter; ala width about half body diameter, usually showing numerous plicae tapering from body towards ala margin or (18) 20-24 (28) deep undulations (P1. VII A, C, D). Body subglobose to ellipsoidal with flattened poles (Pl. VIIB), golden brown, (20) 60-100 (110) $\mu \mathrm{m}$ in diameter; mean ratio of body diameter to total diameter is $1: 2 \cdot 1$, range over the year $1: 1 \cdot 8-2 \cdot 5$, under pressure ratio $1: 1 \cdot 4(\mathrm{Pl}$. VIIL, $M$ ).

Outer body wall with equatorial, conspicuous, broad, smooth alaband, up to $8-10 \mu \mathrm{m}$ wide in large phycomata, with slightly raised smooth margins and one ring of alaband pores somewhat irregularly spaced, $5-10 \mu \mathrm{m}$ apart, on either side of alaband close but externally to each alaband margin (P1. VII G-J). Ala insertion on alaband showing deep undulations (P1. VIIJ). On either side of alaband phycoma wall finely and evenly papillose, appearing stippled, lacking pores other than alaband pores (P1. VIIG-J), forming a broad band covering $0.3-0.5$ of each hemisphere; remaining polar region smooth and lacking pores (Pl. VIIG). Content of phycoma body as described for genus; plastids small disc-shaped, linear to fusiform in side view (Pl. VII K).

Culture studies, referred to briefly under the genus section, have shown that in this species neither the alaband nor the papillose regions adjacent to it are detectable on the very delicate outer wall of young recently formed phycomata measuring up to $27 \mu \mathrm{m}$ total diameter. These studies have also shown that these discrete regions of the phycoma wall are definitely laid down later as the young phycoma increases in age and size (see Table 2). Material must therefore pass out through the wall, or alaband pores, for the growth of both the ala and the body wall. We have not obtained evidence from any Pterosperma species that the equatorial ala is formed by a separate outer membrane as has been suggested by Lohmann (1904).

No gradual increase in the size of the mature phycomata from winter to late spring, as was found within the genus Halosphaera (Parke \& Hartog-Adams, 1965), has been recorded for Pterosperma moebii. From November to February, however, very small mature phycomata have been recorded and studied, their diameters being less than half that of the smallest and less than a quarter that of the largest phycomata of the 'normal' $P$. moebii population occurring in the same tow-net samples.

The phycoma phase of $P$. moebii is present in the sea during all months of the year. 
It is present, but rare, in coastal waters off the south west coast of Britain (Fig. 2) from November to April; it is present in inshore waters from October to May being frequent to very common from December to April; it is absent from June to September. It has been recorded from offshore waters during all months of the year being frequent to common, sometimes abundant, from October to May but rare to very rare from June to September. However this species was common in samples collected by Dr N. Reynolds during August and September 1968 from the Norwegian Sea and Arctic Ocean and in his May samples taken south of Spitzbergen. P. moebii has also been recorded as occurring in large numbers in the southern North Sea in January 1969 and as rare in samples from the N. Atlantic collected in July 1966.

Table 2. Records of the production of motile cells from one Pterosperma moebii phycoma and their transformation into and growth of the daughter-phycoma

Date 1970

$18 \mathrm{Feb}$.

8 Mar.

(new moon 7 Mar.)

9 Mar.

10 Mar.

11-19 Mar.

20-21 Mar.

(full moon 23 Mar.)

2 Apr.

23 Apr.

12 May

24 June
Notes

Phycoma collected, isolated and put into culture medium. Diameter of phycoma - total $175 \mu \mathrm{m}$, body $75 \mu \mathrm{m}$

$10.00 \mathrm{~h}$. Phycoma inner wall already released from outer wall. Contents of inner wall dividing into 4 but still connected together in centre of mass. Empty outer wall checked to confirm species

$10.00 \mathrm{~h}$. Phycoma inner wall now $125 \mu \mathrm{m}$ in diameter with contents dividing into 32 separate masses; each mass with flagella developed and moving actively

$10.00 \mathrm{~h}$. Cells of motile phase, released from inner wall overnight, swimming freely in medium

$10.00 \mathrm{~h}$. Motile cells healthy and dividing

$10.00 \mathrm{~h}$. Motile cells changing over into the phycoma phase; diameter of newly formed daughter-phycomata up to total $27 \mu \mathrm{m}$, body $15 \mu \mathrm{m}$. No evidence was obtained of the presence of alaband pores, alaband or papillose bands on the outer wall from a detailed microscopic examination of the outer wall of the phycoma

Diameter of phycomata about 2 weeks old up to - total $63 \mu \mathrm{m}$, body $33.5 \mu \mathrm{m}$. Microscopic examination of the outer wall of the phycoma shows presence of alaband pores, alaband and narrow papillose region either side of alaband

Diameter of phycomata - total from 97 to $104 \mu \mathrm{m}$, body from 53-54 $\mu \mathrm{m}$ (see Pl. VIIF)

Phycomata diameter up to - total $128 \mu \mathrm{m}$, body $67 \mu \mathrm{m}$; phycoma outer wall showing structure characteristic for species. Contents not fully divided up as lipid vesicles still comparatively large

All phycomata measured; total diameter from 167 to $181 \mu \mathrm{m}$, body diameter from 87 to $95 \mu \mathrm{m}$; these sizes are within the size range recorded for the species from the sea at the same period. Phycomata nearly mature

The release of the motile from the phycoma through the release slit (see p. 246 and Pl. VIID) has been recorded during 9 months of the year, November-July. Releases occurred frequently to commonly from January to April but only rarely during December, May, June and July. No release of motiles has been seen from August to November although phycoma outer walls, apparently recently emptied, have been found in offshore tow-net samples in October and November.

Cells of the motile phase (Pl. VIIIA) $5 \times 4 \times 3$ to $8 \times 6 \times 4 \mu$ m in size; body elliptical to nearly oblong, sometimes reniform, usually convex on one surface slightly concave on the other, somewhat depressed in morphologically anterior-posterior direction. 
Flagella, 4-7 times body diameter in length, arising less than one quarter the cell length in from one margin of concave surface; small caducous hairs and larger striated hairs (Pl. VIIIL) present on flagella; scales of under layer $0.04-0.05 \mu \mathrm{m}$ (Pl. VIIIE); spined scales of outer layer, $0.31 \times 0.19$ to $0.37 \times 0.23 \mu \mathrm{m}$ (Pl. VIIIB, E). Body scales, innermost layer $0.04-0.05 \mu \mathrm{m}$ (P1. VIIIN); outer layers with scales variable in size and design, including types $1,2,3$ and 4 (see p. 248) ranging in size from 0.25 to $0.45 \mu \mathrm{m}$ in diameter (Pl. VIII C, D, F-M). The position of the type 1 scales on the body of the motile cell is as yet uncertain but whole mounts do suggest they, like the type 2 scales, are more numerous on the region of the body from which the flagella emerge. Cell content as for genus; plastid golden brown. Fission in motile phase recorded. Early stages of change from motile to phycoma phase and phycoma growth to maturity also recorded from cultures.

\section{Distribution - as the phycoma phase}

North Atlantic Ocean, Bay of Biscay, English Channel, North Sea, Skagerak (Hensen, 1887), Faeroes - Shetland area (K. R. Gaarder, Oslo, personal communication), off Norwegian West Coast [off Bergen, Jørgensen (1900); Hardangerfjord, A. K. Overland, Oslo, personal communication; Ullsfjord, B. H. Heimdal, Bergen, personal communication], Norwegian Sea, Arctic Ocean, N.E. Pacific Ocean (R. Jowett, British Columbia, personal communication).

\section{Pterosperma eurypteron sp.nov., Parke}

\section{Diagnosis}

(Plate IX A-M)

Phycoma totum (80) 130-190 (228) $\mu \mathrm{m}$ diam., ala aequatoriali maculata corpus cingente latitudine diametrum eius aequante vel superante, e vitta alari angusta paulum conspicua orta, poris ei utrinque juxtim seriatim appositis. Corpus sphaericum, (27) 40-6o (74) $\mu \mathrm{m}$ diam., aureum, membrana exteriore opaca, poris saepe geminatis ornata.

Phycoma, (80) 130-190 (228) $\mu \mathrm{m}$ total diameter, with equatorial maculate ala of the same width as body or wider, arising from narrow, inconspicuous alaband; alaband pores present. Body sphaerical, (27) 40-60 (74) $\mu \mathrm{m}$ in diameter, golden brown, outer wall hebetate containing pores, pores frequently in pairs.

Holotype: Plate IX.

\section{Synonymy}

?'Welliger Statoblast' Hensen (1887, taf. IV, fig. 29)

* Pterosphaera Möbii Jørgensen (1900, p. 48, pro magn.)

Pterosperma moebiusii (Jørgensen) Lohmann (1904, p. 43, taf. IV, figs. 2, 13)

\section{Description of species}

Phycoma, tending to shatter under pressure, with a single equatorial, fragile, deeply undulate, maculate ala of the same width as body or wider, usually showing irregularly

* Jørgensen (1910. p. 48) in his description of Pterosperma moebii gave measurements which were clearly those of a specimen of $P$. eurypteron. 
spaced plicae frequently reaching outer margin of ala or wide and deep undulations, fewer than in P. moebii (Pl. IX A-C). Body sphaerical, not flattened at poles; mean ratio of body diameter to total diameter $1: 3 \cdot 2$, the range over the year being $1: 2 \cdot 8-3.5$, under pressure ratio $1: 2 \cdot 5$.

Outer body wall with equatorial, very inconspicuous, narrow alaband, appearing smoother and having a different texture from that of the body wall adjacent to it; alaband difficult to resolve in smaller phycomata, narrower than in $P$. moebii, usually $4^{-6} \mu \mathrm{m}$ wide in large phycomata, with cuneate smooth margins; a ring of alaband pores, fairly regularly spaced, $3-5 \mu \mathrm{m}$ apart, on either side of alaband close, but externally to, each margin of the alaband (Pl. IXF); ala insertion on alaband showing undulations shallower than in P. moebii (PI. IXF). Outer body wall with a hebetate surface in the vicinity of the alaband $(\mathrm{Pl}$. IXF) but towards the poles the wall surface appears smooth. Clearly discernible pores present in the wall, frequently in pairs close to alaband, remainder irregularly spaced, $5-7 \mu \mathrm{m}$ apart (Pl. IX D-F). Content of phycoma body as described for the genus.

No seasonal increase in the size of mature phycomata, from winter to late spring, has been recorded for $P$. eurypteron. The occurrence of very small mature phycomata has not been observed in this species. From our present knowledge $P$. eurypteron occurs more rarely than P. moebii and appears to have a much more limited distribution both seasonally and geographically. It has not been recorded by us in samples from the Mediterranean, off Portugal, off N. Spain, North Sea, Norwegian Sea or from Arctic waters. In both coastal and inshore waters off the south west coast of Britain it is rare from December to April and absent for the remainder of the year. In offshore waters in the same area, however, it is recorded with little, but increasing frequency from October to June, being absent from all samples collected during August and September. In July 1966 P. eurypteron was not recorded from N. Atlantic samples taken by H.M. Survey Ship 'Zula' between $52-53^{\circ} \mathrm{N}, 19-20^{\circ} \mathrm{W}$ but in October of the same year the species was frequent in samples taken by H.M. Survey Ship 'Welsh Consort' from $51-52^{\circ} \mathrm{N}$, $13-18^{\circ} \mathrm{W}$, although absent from samples from all other stations westward between $51-52^{\circ} \mathrm{N}, 23-52^{\circ} \mathrm{W}$. Our study of the different species occurring in samples in which $P$. eurypteron was present shows that it is invariably accompanied by species of Pachysphaera, particularly $P$. pelagica Ostenf., and it may therefore be an indicator of a particular water mass. Our samples, however, are comparatively meagre and a more extensive area would need to be sampled more frequently over a long period before any true picture of its distribution could be composed.

We have recorded the period of release of the motile cell from the phycoma as being shorter than in Pterosperma moebii, from March to June only, occurring most commonly in June, although empty phycoma outer walls have been recorded from samples taken offshore during July. $P$. eurypteron exhibits a similar lunar and/or semilunar periodicity and release pattern to that of $P$. moebii. A period of from 2 to 3 days has been recorded for $P$. eurypteron from the release of the inner wall to the liberation of motile cells.

Cells of motile phase very fragile, $7 \times 5 \times 3$ to $8 \times 6 \times 4 \mu \mathrm{m}$, ovoid, obconical to cardiform, convex on one surface, flat to slightly concave on the other, depressed in morphological anterior-posterior direction ( $\mathrm{Pl}$. IX G). Flagella, 5-6 times body diameter in 
length, arising from flat surface usually about 0.3 cell length in from one margin; bearing small caducous hairs and larger striated hairs; scales of under layer $0.04-0.05 \mu \mathrm{m}$ (P1. IX G, bottom left); spined scales of outer layer $0.29 \times 0.18$ to $0.35 \times 0.22 \mu \mathrm{m}$ (Pl. IX G, top right). Body scales, innermost layer 0.04-0.05 $\mu \mathrm{m}$ (P1. IX $\mathrm{M}$ ), outer layers with scales variable in size and design, including types $2\left(\mathrm{Pl} . \mathrm{IX}_{\mathrm{H}, \mathrm{J}}\right), 3(\mathrm{Pl}$. IX K, L) and 4 (Pl. IX $\mathrm{M}$ ) ranging in size from 0.25 to $0.40 \mu \mathrm{m}$ diameter. Cell content as for genus, plastid pale gold. Fission in motile phase recorded. Early stages of change from motile to phycoma phase recorded from cultures.

\section{Distribution - as the phycoma phase}

Eastern part of North Atlantic Ocean, Western Approaches to English Channel, western end of English Channel, southern (Hensen) and northern (Jørgensen) North Sea.

\section{Pterosperma porosum sp.nov., Parke}

\section{Diagnosis}

(Plate $\left.\mathrm{X}_{\mathrm{A}-\mathrm{G}}\right)$

Phycoma totum (33.5) 45-55 (64) $\mu \mathrm{m}$ diam., ala aequatoriali maculata fragili cinctum circiter dimidiam partem diametri corporis lata, basi undulante, e superficie corporis continue orta, nulla vitta alari conspicua, membrana exteriore utrinque poris seriatis manifestis ab ala satis distantibus perforata. Corpus subsphaericum, (17) 20-30 (32) $\mu \mathrm{m}$ diam., aureum, membrana exteriore laevi.

Phycoma, (33.5) 45-55 (64) $\mu \mathrm{m}$ total diameter, with equatorial maculate, fragile ala, about half body diameter in width, arising in undulations directly from outer wall surface; no discernible alaband but a single ring of distinct pores in outer wall on either side of ala, lying some distance away from ala insertion on wall. Body subglobose, (17) 20-30 (32) $\mu \mathrm{m}$ in diameter, golden brown, outer wall smooth.

Holotype: Plate X.

\section{Description of species}

Phycoma with a single equatorial, undulate, fragile, maculate ala; ala width about half body diameter, showing 8-9 plicae, tapering from body towards ala margin ( $\mathrm{Pl}$. $\mathrm{X}_{\mathrm{A}-\mathrm{C}}$. Body subglobose, golden brown; mean ratio of body diameter to total $1: 2 \cdot 0$, the range for the year being $1: 1 \cdot 7-2 \cdot 4$. Outer body wall tough, smooth, without any discernible alaband; ala arising, in shallow undulations, directly from the outer wall surface; each hemisphere of outer wall showing a ring of evenly spaced pores not always readily seen, lying some distance away from ala insertion (Pl. XD). Content of the phycoma body as described for the genus.

Very little material of this new taxon has been available for study. Living phycomata have been recorded off the SW coast of Britain, mainly from offshore waters, occasionally from inshore waters, as being rare from February to April and in November. Additional material has been studied from preserved tow-net samples collected for us in August 1969 by Dr P. Williams from the Bay of Biscay and off the $\mathrm{S}$ coast of Portugal. Although the release of the motile phase (Pl. IIIE) from the phycoma has only been recorded during 
February, March and April, this species exhibits a similar lunar and/or semilunar periodicity and release pattern to that of the other species investigated.

Cells of the motile phase fragile, $6 \times 5 \times 3$ to $8 \times 7 \times 4 \mu \mathrm{m}$, subglobose to patelliform, convex on one surface concave on the other, depressed in morphological anteriorposterior direction frequently appearing fabiform in lateral view (Pl. XF). Flagella, usually $3-5$ times body diameter in length, arising from concave surface about 0.25 cell length in from one margin; presence of hairs not recorded; scales of under layer 0.04$0.05 \mu \mathrm{m}$ diameter (Pl. XE, F top right); spined scales of outer layer $0.29 \times 0.17$ to $0.32 \times$ $0.19 \mu \mathrm{m}$ (Pl. XE, F bottom left). Body scales, innermost layer $0.04-0.05 \mu \mathrm{m}$ diameter, outer layers, with scales variable in size and design, including types 2 (Pl. XG bottom right) and 4 (Pl. XG) ranging in size from $0.26-0.33 \mu \mathrm{m}$ in diameter. Cell content as for genus, plastid pale gold. Fission in motile phase recorded.

\section{Distribution - as the phycoma phase}

Off south coast of Portugal $\left(37^{\circ} 26^{\prime} \mathrm{N}, 09^{\circ} 08^{\prime} \mathrm{W}, 1\right.$ Aug. 1969), Bay of Biscay ( $46^{\circ}$ $40^{\prime} \mathrm{N}, 07^{\circ} 30^{\prime}$ W, 4 Aug. 1969), Western Approaches to English Channel, western end of English Channel.

Pterosperma inornatum sp.nov., Parke

\section{Diagnosis}

$$
\text { (Plate XIA-H) }
$$

Phycoma totum (47) 55-70 (108) $\mu \mathrm{m}$ diam., ala aequatoriali maculata plerumque dimidiam partem vel duas partes diametri corporis lata, interdum totam diametrum attingente, basi non undulante, e superficie corporis continue orta, nulla vitta alari nec poris appositis conspicuis. Corpus subsphaericum vel depressum, (23) 25-35 (45) $\mu \mathrm{m}$ diam., aureum, membrana exteriore juxta alam minute ceteroquin crassius papillosa, poris nullis ornata.

Phycoma, (47) 55-70 (108) $\mu \mathrm{m}$ total diameter, with equatorial maculate ala, usually $0.5-0.7$ body diameter in width occasionally width equals body diameter, arising directly from outer wall surface, insertion not undulate; no discernible alaband, no alaband pores. Body subglobose to ellipsoidal, (23) $25-35$ (45) $\mu \mathrm{m}$ in diameter, golden brown; outer wall lacking pores, wall surface showing a very finely papillose band either side of ala insertion, remaining polar regions more coarsely papillose.

Holotype: Plate XI.

\section{Description of species}

Phycoma with a single equatorial undulate maculate ala; ala width from $0.5-0.7$ and occasionally equalling body diameter ( $\mathrm{Pl}$. XIA), generally showing 18-20 plicae, frequently curved, tapering from body towards the ala margin (Pl. XIA, B). Body subglobose to ellipsoidal, golden brown; mean ratio of body diameter to total $1: 2 \cdot 2$, the range being $1: 1 \cdot 7-2 \cdot 4$, under pressure only slight alteration of ratio from $1: 2 \cdot 3$ to $1: 2 \cdot 2$. Outer body wall, lacking pores, without any discernible alaband or alaband pores; ala arising from it directly, with or without shallow undulations (Pl. XIA, B); wall surface, on either side of ala insertion, appearing very finely stippled and forming a zone covering 
about 0.3 of each hemisphere, the remaining polar regions being coarsely papillose (Pl. $\mathrm{XIC})$. Content of the phycoma as described for the genus.

This very rarely occurring species was first detected in our area of investigation in 1969 and only a small number of living phycomata have been isolated for study. Phycomata have been recorded from the edge of the Continental Shelf and inshore waters during July and from the Western Approaches and the western end of the English Channel from January to March. Release of motile cells from the phycoma has only been observed during 1 month, in March 1969 and again in March 1970. Cells of the motile phase (Pl. XID), $6 \times 5 \times 3$ to $7 \times 6 \times 4 \mu \mathrm{m}$, oval to obconical, convex on one surface, concave on the other, depressed in morphological anterior-posterior direction, in lateral view frequently appearing fabiform. Flagella, 8-10 times body diameter in length, arising from concave surface about 0.3 cell length in from one margin; bearing small caducous hairs; large striated hairs not recorded; scales of under layer $0.04-0.05 \mu \mathrm{m}$ in diameter (Pl. XIE, F); spined scales of outer layer $0.28 \times 0.17$ to $0.34 \times 0.21 \mu \mathrm{m}$ (Pl. $\mathrm{XIE}, \mathrm{F})$. Body scales, innermost layer $0.04-0.05 \mu \mathrm{m}(\mathrm{Pl}$. XIH), outer scale layers with scales variable in size and design, including type 2 (Pl. XIG) and type 4 (Pl. XIH), 0.27$0.34 \mu \mathrm{m}$ in diameter. Cell content as for genus, plastid golden brown. Fission in motile phase and early stages of change from motile to phycoma phase recorded from cultures.

\section{Distribution - as the phycoma phase}

Edge of Continental Shelf, Western Approaches to English Channel, western end of English Channel.

\section{Pterosperma undulatum Ostenfeld in Ostenfeld et Schmidt}

\section{Original description}

(Plate XII A-M)

Species figured (fig. 5) and described (p. 151) by Ostenfeld (in Ostenfeld \& Schmidt, 1902) as 'Cell globose with an equatorial, undulate projecting ring; diameter about $45-50 \mu$ '. He considered that his new species differed from $P$. rotondum as it was characterized by the smaller projecting ring (ala) and by the numerous undulations in it. $\mathrm{He}$ recorded this new species as occurring very rarely in the Gulf of Aden and the Red Sea in November 1899 and in the Gulf of Aden in May 1900.

\section{Synonymy}

Trochiscia undulata (Ostenfeld) Lemmermann (1903, p. 349)

\section{Description of species}

Phycoma with a single equatorial, extremely undulate, nonmaculate ala, (29) 35-47 (54) $\mu \mathrm{m}$ total diameter (P1. XII A-D); ala, width $0.2-0.25$ body diameter, always showing numerous plicae tapering from body towards ala margin, plicae usually straight but occasionally curved. Body subglobose to ellipsoidal, flattened at poles, (22) 25-33 (47) $\mu \mathrm{m}$ in diameter; the mean ratio of body diameter to total diameter is $1: 1.5$, the range over the year being $1: 1 \cdot 2-1 \cdot 7$. Outer body wall with equatorial, inconspicuous narrow alaband, 4-5 $\mu \mathrm{m}$ wide, with smooth, lighter coloured central part and darker, coarsely 
papillose, cuneate margins $1.0-1.5 \mu \mathrm{m}$ wide, each containing a ring of alaband pores, 5-6 $\mu \mathrm{m}$ apart, sometimes difficult to resolve (Pl. XIIE, F). Ala insertion on alaband showing shallow undulations (Pl. XIIE). Outer wall with a hebetate very finely papillose surface, lacking pores other than alaband pores, appearing darker than the alaband; tending to shatter under pressure after treatment with $\mathrm{KI}_{3}$ unless extreme care is exercised. Content of the phycoma body as described for the genus; starch shells around pyrenoids clearly seen after treatment with $\mathrm{KI}_{3}$ (Pl. XIIG).

No gradual increase in size of mature phycomata from winter to late spring has been recorded, nor have very small mature phycomata been reported for this species. The phycoma phase is present in the sea during all months of the year. Off the south west coast of Britain (Fig. 2) it is present in coastal and inshore waters from late October to early May, being very rarely recorded October to December. In offshore waters in the same area it is absent only during August and September, being not uncommon from December to April but rare during October, November, May-July. Although not recorded from our area of investigation during the months of August and September it was not uncommon, sometimes quite frequent, in samples collected for us by $\mathrm{Dr} \mathrm{N}$. Reynolds from the northern North Sea during August-September 1968.

The release of motile cells from the phycoma has been obtained during only four months of the year February to May, the releases occurring more frequently during March and April. Empty outer phycoma walls however have been recorded from our samples taken during December and January but no releases were obtained under culture conditions during these months.

Cells of the motile phase (Pl. XIIH), $5 \times 4 \times 3$ to $6 \times 5 \times 4 \mu \mathrm{m}$, sphaeroidal to ellipsoidal, convex on one surface, concave on the other, depressed in morphological anteriorposterior direction. Flagella, 5-8 times body diameter in length, arising from concave surface usually about 0.3 cell length in from one margin; scales of under layer $0.04-$ $0.05 \mu \mathrm{m}$ diameter (Pl. XIIJ); spined scales of outer layer $0.30 \times 0.17$ to $0.36 \times 0.21 \mu \mathrm{m}$ (Pl. XIIJ, K). Body scales, innermost layer $0.04-0.05 \mu \mathrm{m}$ (Pl. XIIM), outer scale layers, with scales variable in size and design, including type 2 (Pl. XIIL top right) and type 4 (Pl. XIIL) ranging in size from $0.23-0.37 \mu \mathrm{m}$ in diameter. Cell content as for genus, plastid golden brown. Fission in motile phase recorded.

One of the most rapid phase changes was recorded for P. undulatum. On 5 May 1967 a mature phycoma released motile cells in culture which started to turn back into phycomata on 8-9 May 1967, the date of the new moon being 9 May 1967. The young, newly formed phycoma with ala measured $9-10 \mu \mathrm{m}$ in diameter, a size comparable to that given by Schiller (1925, p. 74, text-fig. J) for P. joergensenii Schiller, his figure for which appears very similar to our Plate XIIA, of $P$. undulatum. In the diagnosis of $P$. joergensenii however, the size given by Schiller for the width of the ala is approximately half that given for the body, such proportions not being borne out by his illustration. Owing to this discrepancy it is not possible to know whether $P$. joergensenii Schiller, collected in the Adriatic, should be considered synonymous with $P$. undulatum Ostenfeld. 


\title{
Distribution - as the phycoma phase
}

Gulf of Aden (Ostenfeld, 1902), Red Sea (Ostenfeld, 1902), Western Approaches to English Channel, western end of English Channel, southern and northern North Sea, Gulf of Mexico (K. R. Gaarder, Oslo, personal communication) Bahamas (K. R. Gaarder, Oslo, personal communication).

\section{Pterosperma citriforme sp.nov., Parke}

\section{Diagnosis}

\author{
(Plates XIIIA-K, XIVA, B)
}

Phycoma (20) 33-54 (60) $\mu \mathrm{m}$ diam., ala aequatoriali laevi vix conspicua cinctum circiter $1.5 \mu \mathrm{m}$ lata e vitta alari orta minus quam $1 \mu \mathrm{m}$ lata laevi, praeter margines elevatos manifestos crasse papillosos 1-2 $\mu$ m latos, poris seriatis $4-5 \mu \mathrm{m}$ distantibus utrinque ei juxta appositis. Corpus sphaericum vel depressum a latere visum citri fructum revocans, viridule aureum, membrana exteriore laevi, poris praeter vittae appositos nullis.

Phycoma, (20) 33-54 (60) $\mu \mathrm{m}$ in size, with equatorial smooth ala, hardly discernible, about $1.5 \mu \mathrm{m}$ in width, arising from a narrow smooth alaband less than $1 \mu \mathrm{m}$ wide, with raised, obvious, coarsely papillose margins, each 1-2 $\mu$ m wide; alaband pores present, 4-5 $\mu \mathrm{m}$ apart. Body globose to ellipsoidal, appearing citriform from the side, greenish gold, outer wall smooth, lacking pores.

Holotype: Plate XIII.

\section{Description of species}

Phycoma, with a single, hardly detectable extremely narrow, smooth, slightly undulate, fragile ala, only $1 \cdot 25-1.5 \mu \mathrm{m}$, exceptionally $2 \mu \mathrm{m}$, in width (Pl. XIII ${ }_{A-E}$ ). Body globose to citriform (Pl. XIIIC, E), greenish gold to golden brown; the mean ratio of body diameter to total diameter is $1: 1 \cdot 1$. Outer body wall with equatorial, clearly discernible, raised, coarsely papillose alaband, $3.5-4.5 \mu \mathrm{m}$ wide, with a narrow depressed central smooth channel bearing the slightly undulating ala (PI. XIIIF-H); smooth channel less than $1 \mu \mathrm{m}$ wide, each raised papillose margin up to $2 \mu \mathrm{m}$ wide, width depending on whether wall with or without contents (Pl. XIIIF, J); alaband visible on phycoma with contents (Pl. XIIIA-C, E), also showing clearly as wall protruberances in optical section (PI. XIIIF); ala only discernible on an empty outer wall or on one from which the contents have been forced out by pressure (Pl. XIII G, H). Ring of alaband pores present, fairly regularly spaced, $4-5 \mu \mathrm{m}$ apart, on either side of alaband close but externally to each alaband margin, pores irregularly alternate on opposite sides of band (PI. XIIIG, $\mathrm{J}$ ); ala insertion on alaband channel showing very shallow undulations. Outer wall smooth, lacking pores except for alaband pores. Content of the phycoma body as described for the genus; in young phycomata starch shells, triangular to roughly oblong in shape, become conspicuous after treatment with $\mathrm{KI}_{3}$ (Pl. XIIIE).

Although no gradual increase in the size of mature phycomata from winter to late spring has been recorded for this species the range of size of mature phycomata col- 


\section{Table 3. Comparative characters of Pterosperma species with a single equatorial ala}

\section{Characters}

\section{PHYCOMA PHASE}

Size at maturity

\section{Total diameter $(\mu \mathrm{m})$}

Body diameter $(\mu \mathrm{m})$

Mean ratio of body

to total diameter

Appearance of ala

Shape of phycoma body

Alaband

Ala insertion

Alaband pores in outer wall

Pores other than alaband pores in outer wall

Appearance of external surface of phycoma outer wall

Recorded occurrence

W. Channel and Bay of Biscay

Recorded mature in these areas

MOTILE PHASE

Size $(\mu \mathrm{m})$ of cell

Flagella length

Body shape

Types of scales on body Illustrations

Release of motile

phase recorded
$P$. rotondum

P. moebii

P. eurypteron
(47) $55-87$ (94)

(20) $25-40$ (44)

$1-2 \cdot 2$

Rugose or blotchy

Globose occasionally subglobose (Pl. VIC)

Present-inconspicuous smooth with raised scabrellous margins (Pl. VIJ)

Shallow undulations (Pl. VIH)

One ring of distinct pores on either side of alaband lying close but externally to each margin of alaband (Pl. VIJ)

Large spaced pores in ca. 0.75 of each hemisphere appearing as deep polar poroid caps (PI. VIG, $\mathrm{H}$ )

About 0.25 adjacent to alaband coarsely papillate (blotchy) without pores other than alaband pores; remainder of wall poroid and finely papillate (Pl. VIG, J)

None

None

No living material seen

$5 \times 4 \times 3-8 \times 6 \times 4$ 4-7 times body diam. Ellipsoid-oblong

Types 1, 2, 3, 4 . Pl. VIII. Nov.-July with well-flattened poles. (P1. VIIB)

Present-conspicuous broad, smooth with margins (Pl. VIIJ)

Deep undulations (Pl. VII J)

One ring of distinct (Pl. VII G, H)

None (P1. VII G) appearing finely and evenly papillose(Pl. VII G-J)

Jan.-Dec.
(80) 130-190 (228)

(27) $40-60 \quad(74)$

$1-3 \cdot 2$

Blotchy - maculate

Globose

Subglobose to ellipsoidal slightly raised smooth somewhat irregularly spaced pores on either side of alaband lying close but externally to each margin of alaband

About $0.3-0.5$ of each hemisphere adjacent to alaband a broad band remaining polar region non-poroid and smooth

Oct.-June

Mar.-June

$7 \times 5 \times 3-8 \times 6 \times 4$ 5-6 times body diam. Ovoid, obconicalcardiform

Types 2, 3, 4 . PI. IX. Mar.-June 
Table 3 (cont.)

\section{Characters}

P. porosum

PHYCOMA PHASE

Size at maturity
Total diameter $(\mu \mathrm{m})$
Body diameter $(\mu \mathrm{m})$
Mean ratio of body
to total diameter
Appearance of ala
Shape of phycoma
body
(33.5) $45-55$ (64)
(17) $20-30(32)$
(47) $55-70(108)$
(23) $25-35$ (45)
$1-2$
$1-2 \cdot 2$
Maculate - fragile Maculate
Subglobose (Pl. XB, Subglobose to
c)

Alaband
(29) $35-47(54)$
(22) $25-33(47)$
$1-1 \cdot 5$

Smooth

Subglobose to ellipsoidal with

flattened poles

(PI. XIIC)
Absent-ala appears to Absent-ala appears arise directly from wall surface to arise directly from wall surface

\section{Ala insertion \\ Alaband pores in outer wall}

\section{Pores other than alaband pores in outer wall}

Appearance of external surface of phycoma outer wall
Shallow undulations

In each hemisphere None

a ring of evenly spaced inconspicuous pores lying some distance from ala insertion (Pl. XD)

None

Smooth to slightly granular in appearance tions

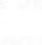

None
With or without shallow undula-

Polar region of both hemispheres coarsely papillose;

\section{Recorded occurrence W. Channel and Bay of Biscay}

Recorded mature in these areas MOTILE PHASE

Size $(\mu \mathrm{m})$ of cell Flagella length

Body shape

Types of scales on body Illustrations

Release of motile phase recorded
Feb.-Apr., Aug., Nov.

Feb.-Apr.

$6 \times 5 \times 3-8 \times 7 \times 4$

3-5 times body diam. 8-10 times body diam.

Subglobosepatelliform

Types 2, 4 .

Pl. X.

Feb.-Apr.

Jan.-Mar., July

Mar.

Types 2, 4 .

$\mathrm{Pl}$ XI.

Mar. either side of ala wall surface appearing finely stippled and covering $\mathrm{ca}$. 0.3 of each hemisphere (PI. XIB, C)

Feb.-May

A hebetate very finely papillose surface

narrow, light-toned edges and wall darker; margins wedge-shaped and coarsely papillose (PI. XIIE)

Shallow undulations (Pl. XIIE)

One ring of pores, fairly regularly spaced, on either side of alaband close to cuneate margins of alaband (PI. XIIF)

None

Oct.-July

Jan.-Dec.

Oval-obconical

$5 \times 4 \times 3-6 \times 5 \times 4$

5-8 times body diam. diam.

Spherical-ellipsoidal

Oval-oblong

Types 2, 4 . Nov.-June
(20) $33-54(60)$

$1->1 \cdot 1$

Smooth

Globose to citriform

(Pl. XIII A-E)

resent-conspicuous, smooth with raised coarsely papillose margins (Pl. XIII G-J)

Very shallow undulations $(\mathrm{Pl}$. XIII G, H)

One ring of pores, fairly regularly spaced, on either side of alaband close to papillose margins of alaband (PI. XIII G-J)

None

Smooth

$4 \times 3 \times 2-8 \times 6 \times 4$

6-10 times body Pls. XIII, XIV. 
lected during any month of the year is very considerable. The largest mature phycomata is usually about three times the size of the smallest.

In our area of investigation (Fig. 2) P. citriforme is one of the most commonly occurring species, being recorded during all months of the year. In the coastal waters it is not uncommon from October to January, frequent to very common from February to April, rare in May and September and absent during June, July and August. Its occurrence is similar in the inshore waters only differing in being present, in small numbers, from June to August. In offshore waters it is frequent to very common from October to the end of April and less so from May to September. However, in the northern North Sea it was frequent to very common in samples collected from $54-60^{\circ} \mathrm{N}$ by $\mathrm{Dr} \mathrm{N}$. Reynolds in early September 1968 and was recorded from the Arctic Ocean at $71^{\circ} \mathrm{N}$ in May 1968. In 1969 it was not uncommon in samples collected by Dr P. Williams from $36-46^{\circ} \mathrm{N}$ during late July and early August in the western Mediterranean, entrance to Gibraltar Straits, off S. Portugal and from the Bay of Biscay.

A few phycomata of two undescribed species, rather similar to $P$. citriforme, have been collected but insufficient material was obtained to enable us to investigate the taxa in detail.

The release of motile cells from the phycoma has been recorded from November to June, the sizes of the mature phycomata ranging from 20 to $60 \mu \mathrm{m}$. Releases occurred frequently from November to January, commonly to very commonly from February to April but only rarely during May and June. Measurements made before and after release of the inner wall showed that the phycoma outer wall had contracted slightly in size after the contents had been released, e.g. before release $48 \times 45 \mu \mathrm{m}$, after release $43 \times 40 \mu \mathrm{m}$, the shape of the outer wall most frequently appearing as illustrated in Plate XIIID. Although the actual release of the motile cells could be obtained readily and followed the same lunar and semilunar pattern of release as other species the motile cells could not be maintained in culture for more than about a month although a variety of media and different conditions of cultures were frequently tested.

Cells of the motile phase (Pl. XIII ), $4 \times 3 \times 2$ to $8 \times 6 \times 4 \mu \mathrm{m}$, oval to oblong, convex on one surface, concave on the other, depressed in morphological anterior-posterior direction, in lateral view frequently appearing fabiform. Flagella, 6-10 times body diameter in length, arising from concave surface about 0.3 cell length in from one margin; small caducous hairs and larger striated hairs present on flagella (Pl. XIVA, B); scales of under layer $0.04-0.05 \mu \mathrm{m}$, spined scales of outer layer, $0.28 \times 0.18$ to $0.34 \times 0.22 \mu \mathrm{m}$ (Pl. XIVA, B). Body scales (Pl. XIVA, B), innermost layer, $0.04-0.05 \mu \mathrm{m}$, outer scale layers with scales variable in size and design, including type 2 and type 4 , ranging in size from $0.28-0.33 \mu \mathrm{m}$ in diameter. Cell content as for genus, plastid usually greenish gold. Fission in motile phase recorded. Early stages of change from motile to phycoma phase recorded from cultures.

\section{Distribution - as the phycoma phase}

Western Mediterranean Sea, entrance to Gibraltar Straits, off S. Portugal, Bay of Biscay, Western Approaches to English Channel, western end of English Channel, southern and northern North Sea, Arctic Ocean, N.E. Pacific Ocean (R. Jowett, British Columbia, personal communication). 


\section{KEY TO SPECIES OF PTEROSPERMA}

1. Phycoma with a single equatorial ala Phycoma with alae not emerging equatorially

2. Phycoma without discernible alaband

Phycoma with discernible alaband

3. Outer wall of phycoma lacking pores, coarsely papillose except for distinct finely papillose band either side of ala

Outer wall of phycoma smooth, ring of pores either side of ala

P. porosum (p. 261)

4. Phycoma outer wall with pores, in addition to alaband pores

Phycoma outer wall lacking pores except for alaband pores

5. Phycoma outer wall with distinct papillose region either side of ala, remainder of wall with pores distributed singly

Phycoma outer wall hebetate with pores in pairs close to alaband

6. Phycoma outer wall with distinct papillose band either side of ala

P. rotondum (p. 255)

Phycoma outer wall without papillose band either side of ala

P. eurypteron (p. 259)

P. moebii (p. 256)

7. Ala extremely undulate, $0 \cdot 20-0 \cdot 25$ body diameter

Ala hardly detectable, alaband obvious

$\star$ Not dealt with in this paper.

P. undulatum (p. 263)

P. citriforme (p. 265)

\section{REFERENCES}

Boalch, G. T. \& Mommaerts, J. P., 1969. A new punctate species of Halosphaera. Fournal of the Marine Biological Association of the United Kingdom, 49, 129-139.

Bourrelly, P., 1957. Recherches sur les Chrysophycées: Morphologie, Phylogénie, Systématique. Revue algologique, Mémoire Hors-Série, 1, 1-412.

Bourrelly, P., 1968. Les Algues d'eau douce. Tome II. Les Algues jaunes et brunes Chrysophycées, Phéophycées, Xanthophycées et Diatomées. $43^{8}$ pp. Paris: N. Boubée.

Christensen, T., 1966. Alger. In Botanik, vol. 2 (Systematisk Botanik), Nr. 2, Udg. 2 (ed. T. W. Böcher, M. Lange and T. Sørensen), $180 \mathrm{pp}$. København: Munksgaard.

Cleve, P. T., 1900. Notes on some Atlantic plankton-organisms. Kungliga Svenska vetenskapsakadamiens handlingar, 34 (1), 1-22.

EISENACK, A., 1972. Kritische Bemerkung zur Gattung Pterospermopsis (Chlorophyta, Prasinophyceae). Neues fahrbuch für Geologie und Paläontologie. Monatshefte, 10, 596-601.

Fotт, B., 1959. Algenkunde. 482 pp. Jena: Gustav Fischer.

FotT, B., 1971. Algenkunde. 581 pp. Jena: Gustav Fischer.

GAARDER, K. R., 1954. Coccolithineae, Silicoflagellatae, Pterospermataceae and other forms from the 'Michael Sars' North Atlantic deep sea expedition 1910. Report on the Scientific Results of the 'Michael Sars' North Atlantic Deep Sea Expedition 1910, 2 (4), 1-20.

Gran, H. H., 1902. Das Plankton des norwegischen Nordmeeres. Report on Norwegian Fishery and Marine Investigations, 2(5), 1-222.

Hensen, V., 1887. Ueber die Bestimmung des Plankton's oder des im Meere treibenden Materials an Pflanzen und Thieren. Fünfter Bericht der Kommission zur wissenschaftlichen Untersuchung der deutschen Meere in Kiel für die fahre 1882 bis 1886, pp. 1-102.

JefFreY, S. W., 1976. A report of green algal pigments in the central north Pacific Ocean. Marine Biology, 37, 33-37.

Jørgensen, E., 1900. Protophyten und Protozoën im Plankton aus der norwegischen Westküste. Bergens museums åarbog for 1899 , No. 6, 1-112.

Jux, U., 1969a. Über den Feinbau der Zystenwandung von Pachysphaera marshalliae Parke, 1966. Palaeontographica, B, 125, 104-111.

Jux, U., 1969b. Über den Feinbau der Zystenwandung von Halosphaera Schmitz, 1878. Palaeontographica, B, 128, 48-55.

KütZING, F. T., 1845. Phycologia Germanica. 340 pp. Nordhausen.

Lemmermann, E., 1903. Das Phytoplankton des Meeres. II. Beitrag. Abhandlungen herausgegeben vom Naturwissenschaftlichen Verein zu Bremen, 17, 341-418.

Loeblich, A. R., JR., \& Loeblich, A. R., III, 1970. Index to the genera, subgenera, and sections of the Pyrrophyta, IV. Fournal of Paleontology, 44, 536-543. 
Lohmann, H., 1904. Eier und sogenannte Cysten der Plankton-Expedition. Ergebnisse der Plankton-Expedition der Humboldt-Stiftung, 4. N, 1-52,

MANTON, I., OATES, K. \& PARKE, M., 1963. Observations on the fine structure of the pyramimonas stage of Halosphaera and preliminary observations on three species of Pyramimonas. Fournal of the Marine Biological Association of the United Kingdom, 43, 225-238.

Manton, I. \& PARKe, M., 1960. Further observations on small green flagellates with special reference to possible relatives of Chromalina pusilla Butcher. Fournal of the Marine Biological Association of the United Kingdom, 39, 275-298.

Meunier, A., 1910. Microplankton des mers de Barents et de Kara. Duc d'Orléans Campagne Arctique de 1907. 355 pp. Bruxelles: Bulens.

Ostenfeld, C. H., 1903. Phytoplankton from the sea around the Faeroes. In Botany of the Faeroes, pp. 558-611. London: John Wheldon.

OSTENFELD, C. H., 1910. Marine plankton from the East-Greenland sea. 1. List of diatoms and flagellates. Meddelelser om Gronland, 43, 257-285.

Ostenfeld, C. H., 1913. De Danske Farvandes Plankton. Phytoplankton og Protozoer. Kongelige Danske Videnskabernes Selskabs Skrifter, 7 Raekke, Naturvidenskabelig og Mathematisk Afdeling, 9, 117-478.

Ostenfeld, C. H. \& Schmidt, J., 1902. Plankton fra det Røde Hav og Adenbugten. [Plankton from the Red Sea and the Gulf of Aden.] Videnskabelige Meddelelser fra den naturhistoriske Forening $i$ Kjobenhavn for Aaret 1901, pp. 141-182.

Papenfuss, G. F., 1955. Classification of the algae. In A Century of Progress in the Natural Sciences 1853-1953 (ed. E. L. Kessel), pp. 115-224. San Francisco: California Academy of Sciences.

PARKe, M., 1966. The genus Pachysphaera (Prasinophyceae). In Some Contemporary Studies in Marine Science (ed. H. Barnes), pp. 555-563. London: Allen \& Unwin.

Parke, M. \& Adams, I., 1961. The Pyramimonas-like motile stage of Halosphaera viridis Schmitz. Bulletin of the Research Council of Israel, 10 D, 94-100.

PARKE, M. \& Dixon, P. S., 1964. A revised check-list of British marine algae. Fournal of the Marine Biological Association of the United Kingdom, 44, 499-542.

PARKe, M. \& Dixon, P. S., 1968. Check-list of British Marine Algae - second revision. Fournal of the Marine Biological Association of the United Kingdom, 48, 783-832.

PARKE, M. \& Dixon, P. S., 1976. Check-list of British Marine Algae - third revision. Fournal of the Marine Biological Association of the United Kingdom, 56, 527-594.

PARKe, M. \& HARTOG-AdAMs, I.DEN, 1965. Three species of Halosphaera. Fournal of the Marine Biological Association of the United Kingdom, 45, 537-557.

PARKe, M. \& Rayns, D. G., 1964. Studies on marine flagellates. VII. Nephroselmis gilva sp.nov. and some allied forms. Fournal of the Marine Biological Association of the United Kingdom, 44, 209-217.

Pouchet, G., 1893. Chapter X. Histoire naturelle. In Voyage de 'La Manche' à l'Ile Fan-Mayen et au Spitzberg (fuillet-Août 1892). Nouvelles archives des missions scientifiques et littéraires, 5, $155-217$.

Prescott, G. W., 1969. The Algae: a Review. 436 pp. London: Nelson.

SCHILleR, J., 1913. Vorläufige Ergebnisse der Phytoplanktonuntersuchungen auf den Fahrten S.M.S. 'Najade' in der Adria. II. Flagellaten und Chlorophyceen. Sitzungsberichte der Akadamie der Wissenschaften in Wien, Mathematisch-naturwissenschaftliche Klasse, 122, 621-630.

SCHILlER, J., 1925. Die planktonischen Vegetationen des adriatischen Meeres. B. Chrysomonadina, Heterokontae, Cryptomonadina, Eugleninae, Volvocales. 1. Systematischer Teil. Archiv für Protistenkunde, 53, 59-123.

Silva, P. C., 1970. Remarks on algal nomenclature. IV. Taxon, 19, 941-945.

Swale, E. M. F., 1973. A third layer of body scales in Pyramimonas tetrarhynchus Schmarda. British Phycological fournal, 8, 95-99.

Swale, E. M. F. \& Belcher, J. H., 1968. The external morphology of the type species of Pyramimonas ( $P$. tetrarhynchus Schmarda) by electron microscopy. Proceedings of the Linnean Society of London, 179, 77-81.

ThORRINGTON-Smith, M., 1970. Some new and little known phytoplankton forms from the west Indian Ocean. British Phycological fournal, 5, 51-56.

Wall, D. \& DALE, B., 1968. Modern dinoflagellate cysts and evolution of the Peridinales. Micropaleontology, 14, 265-304. 


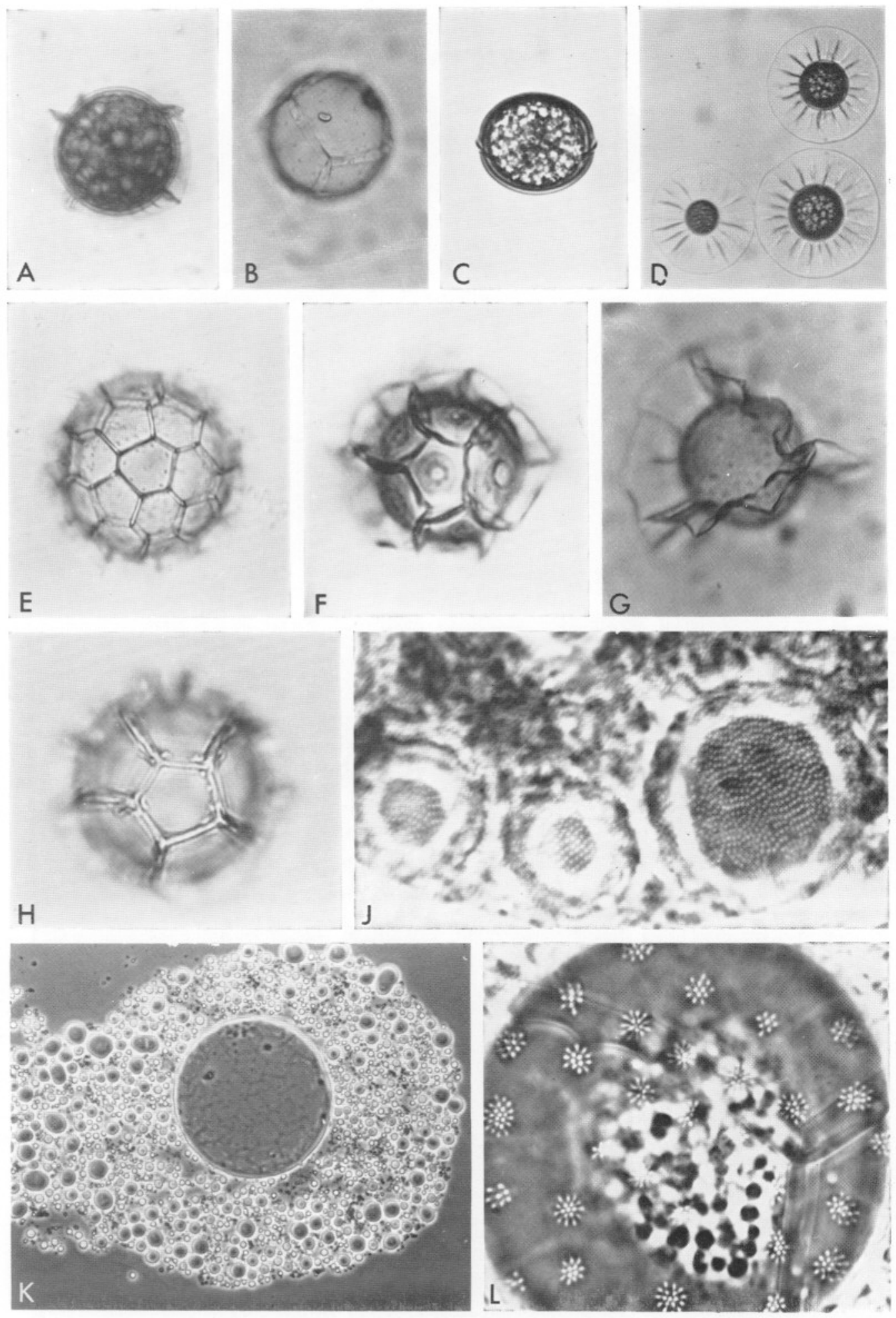

(Facing p. 270) 


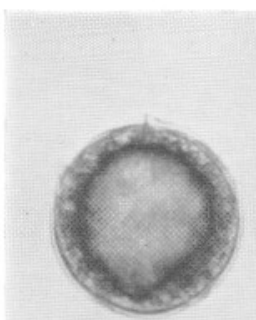

A

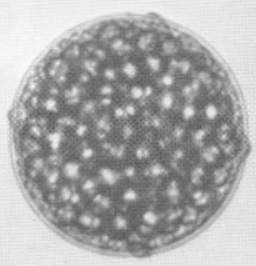

E
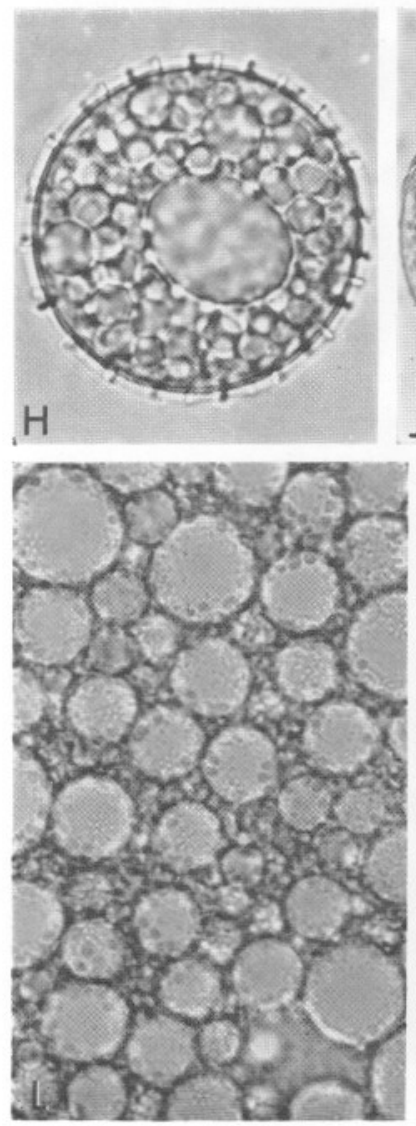

B
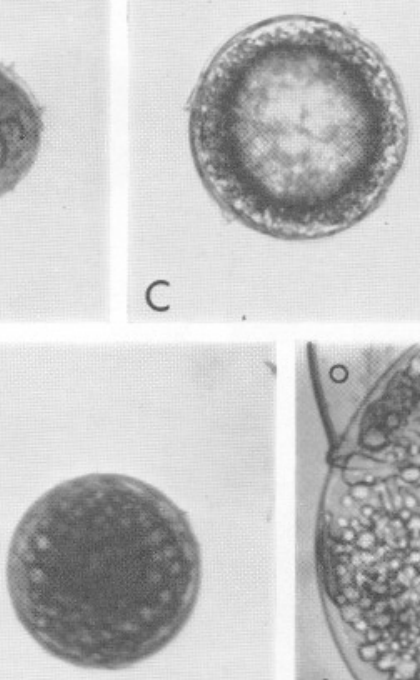

F
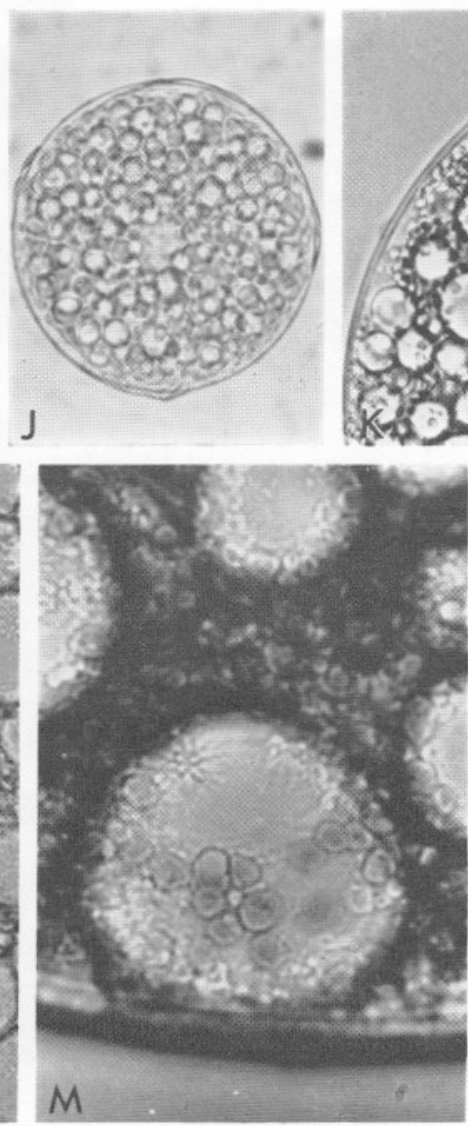

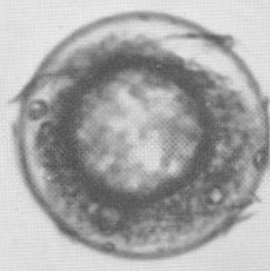

D
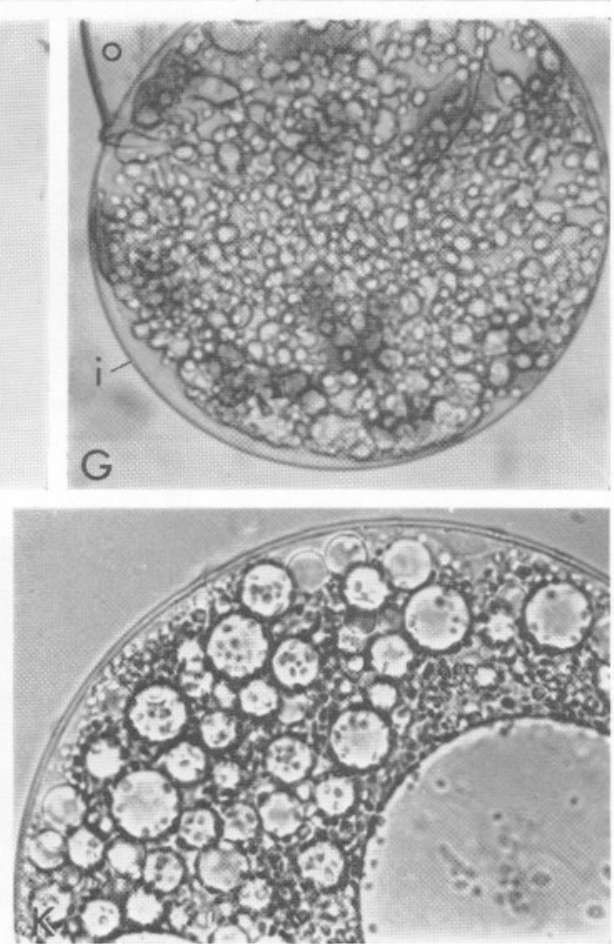

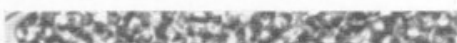

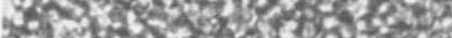

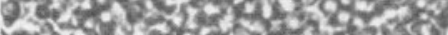
$320.65 \%$.

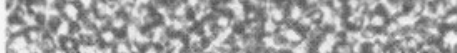

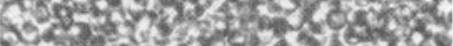

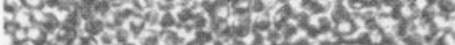

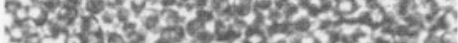

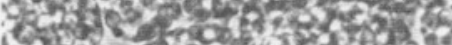
Gor d H (1) 4. 0 .

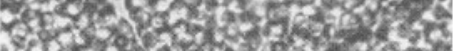

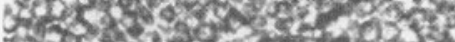

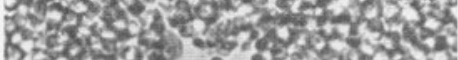

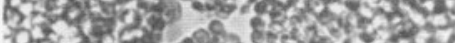

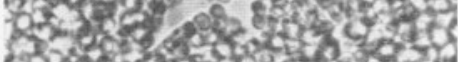
2000102075

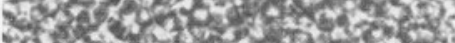

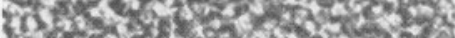

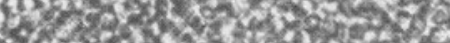

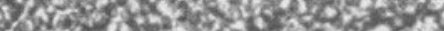

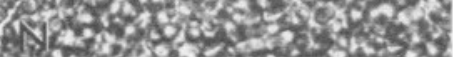



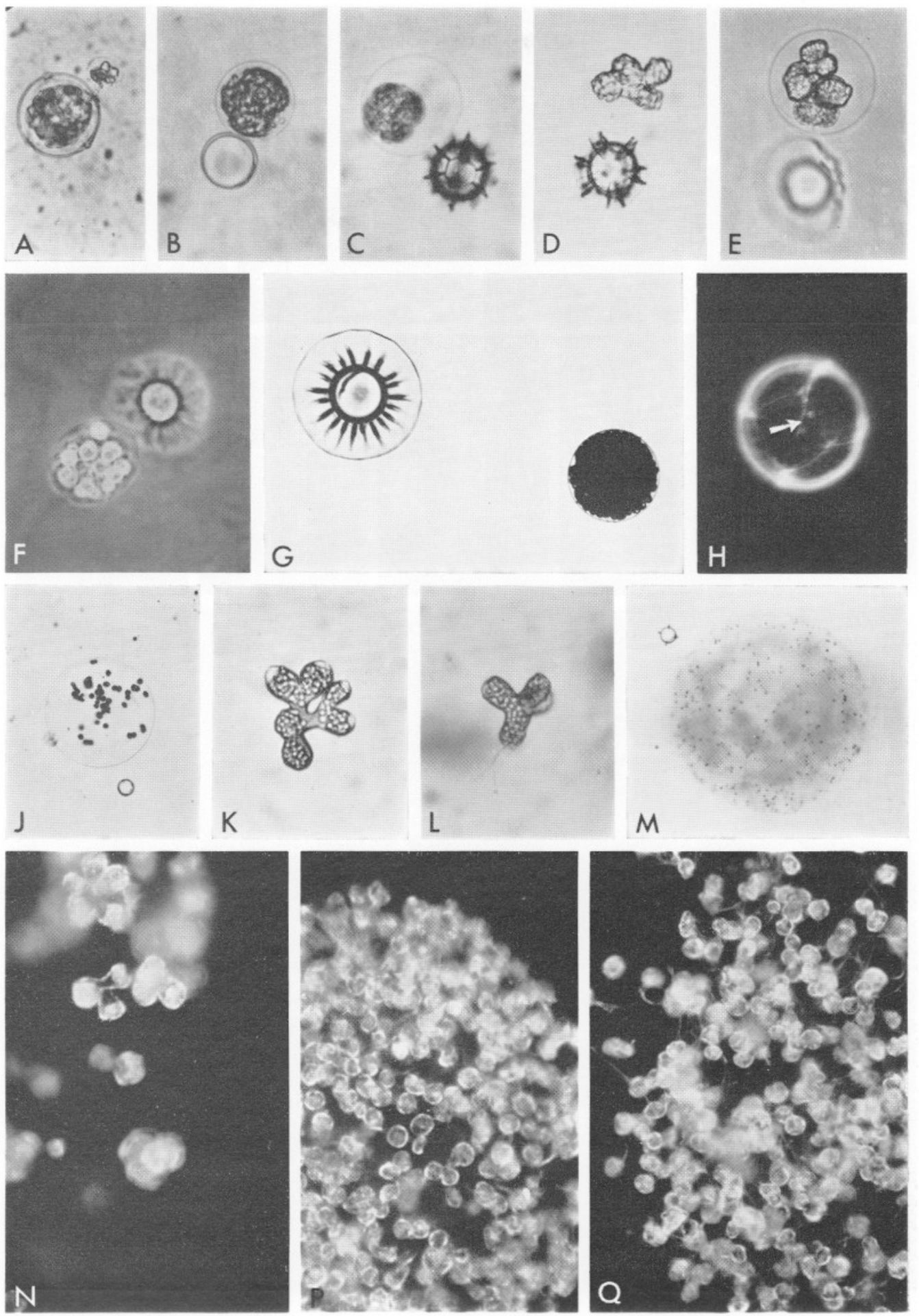

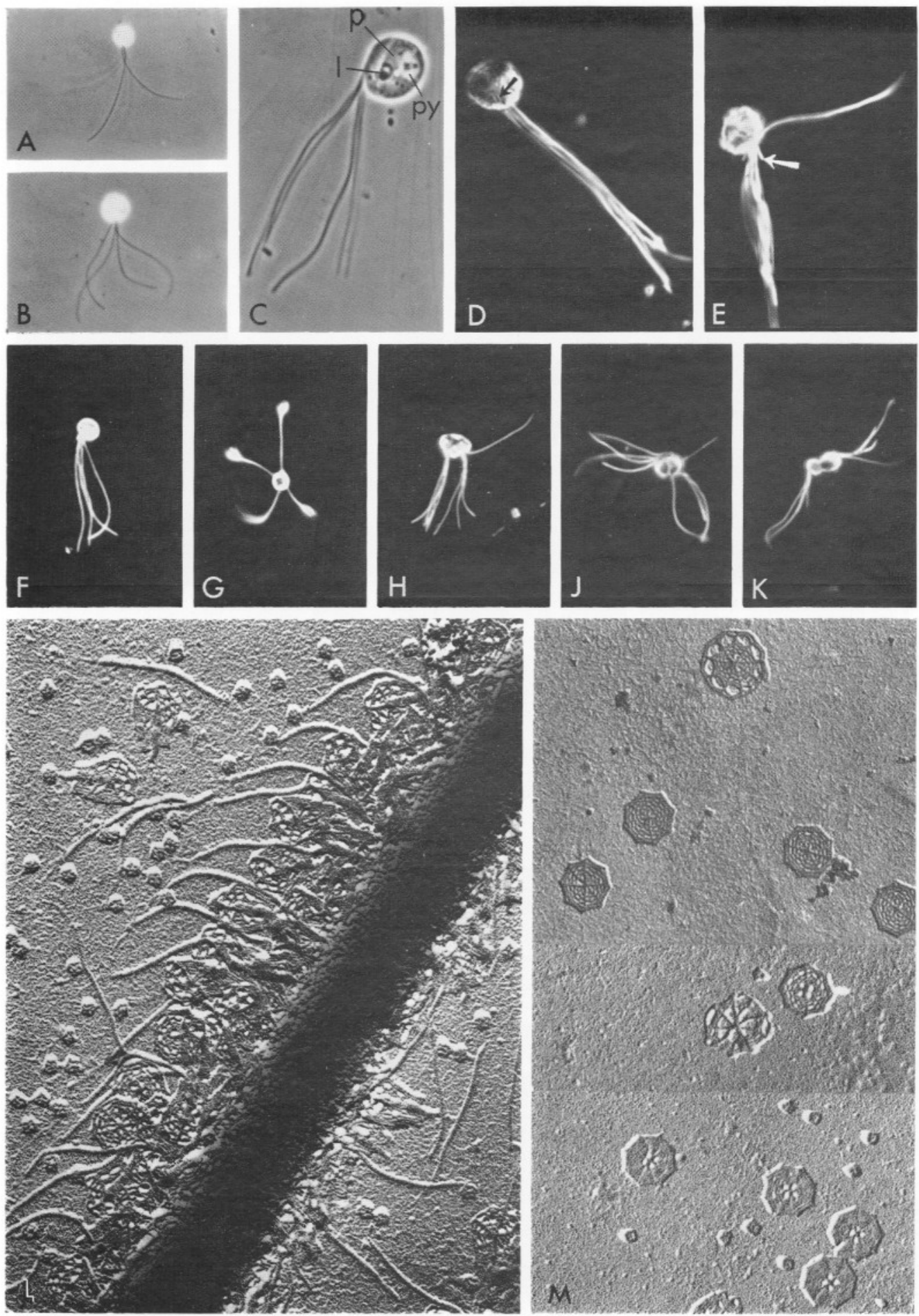

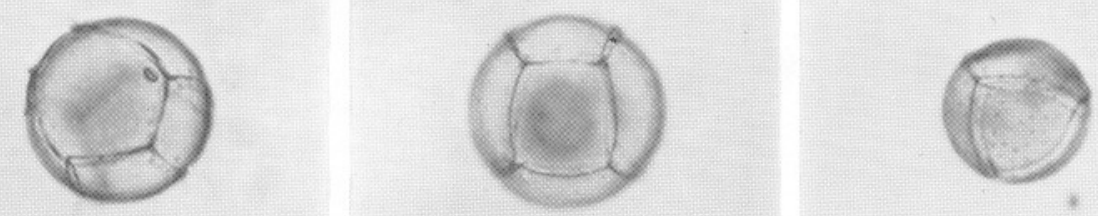

A

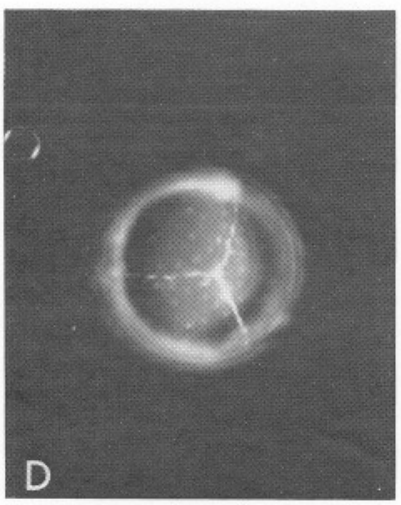

B

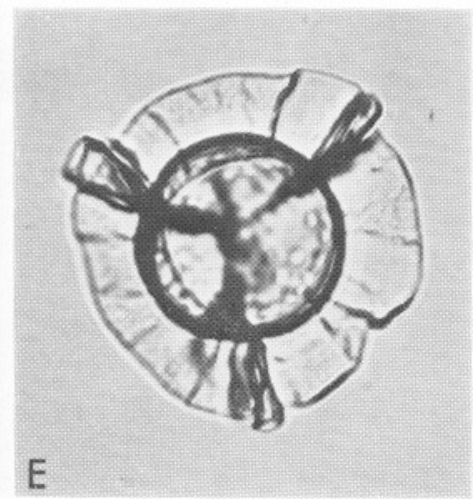

C

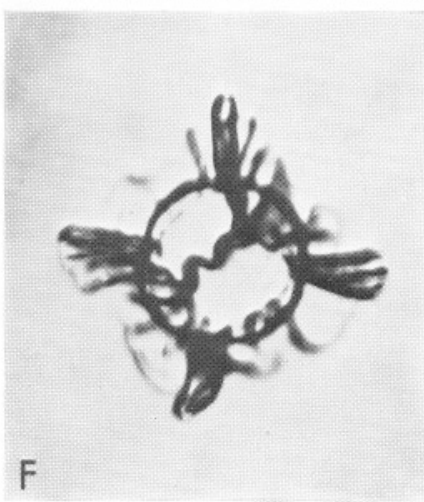

F

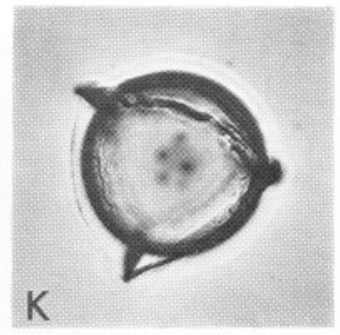

H

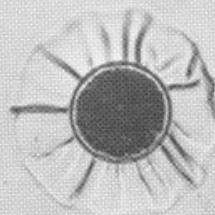

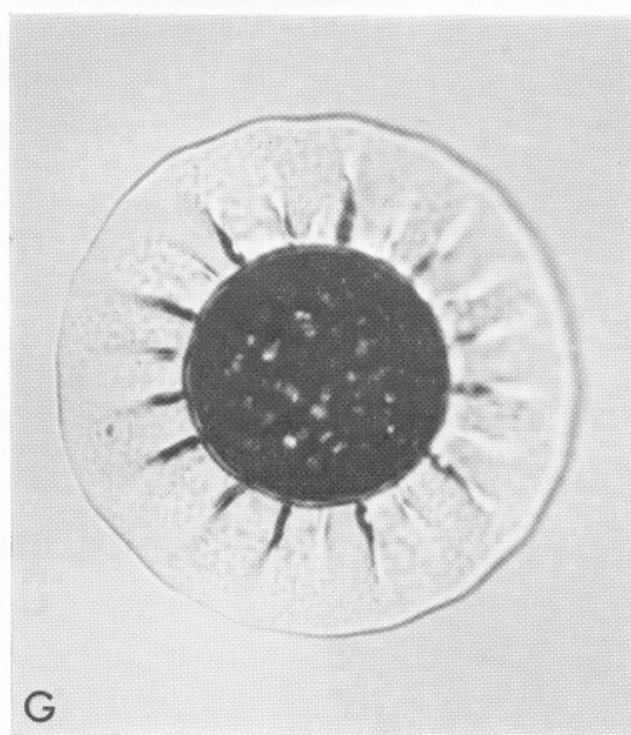
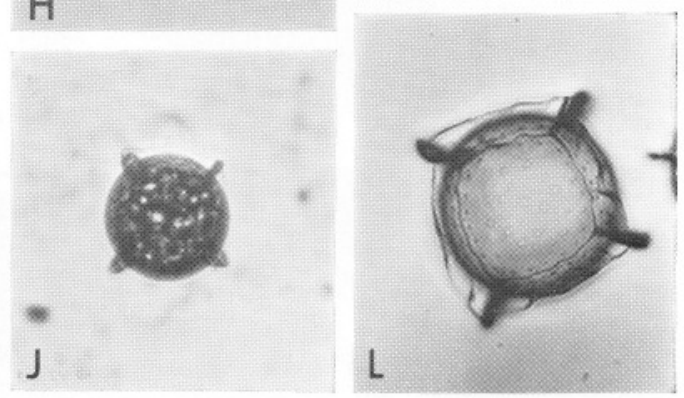

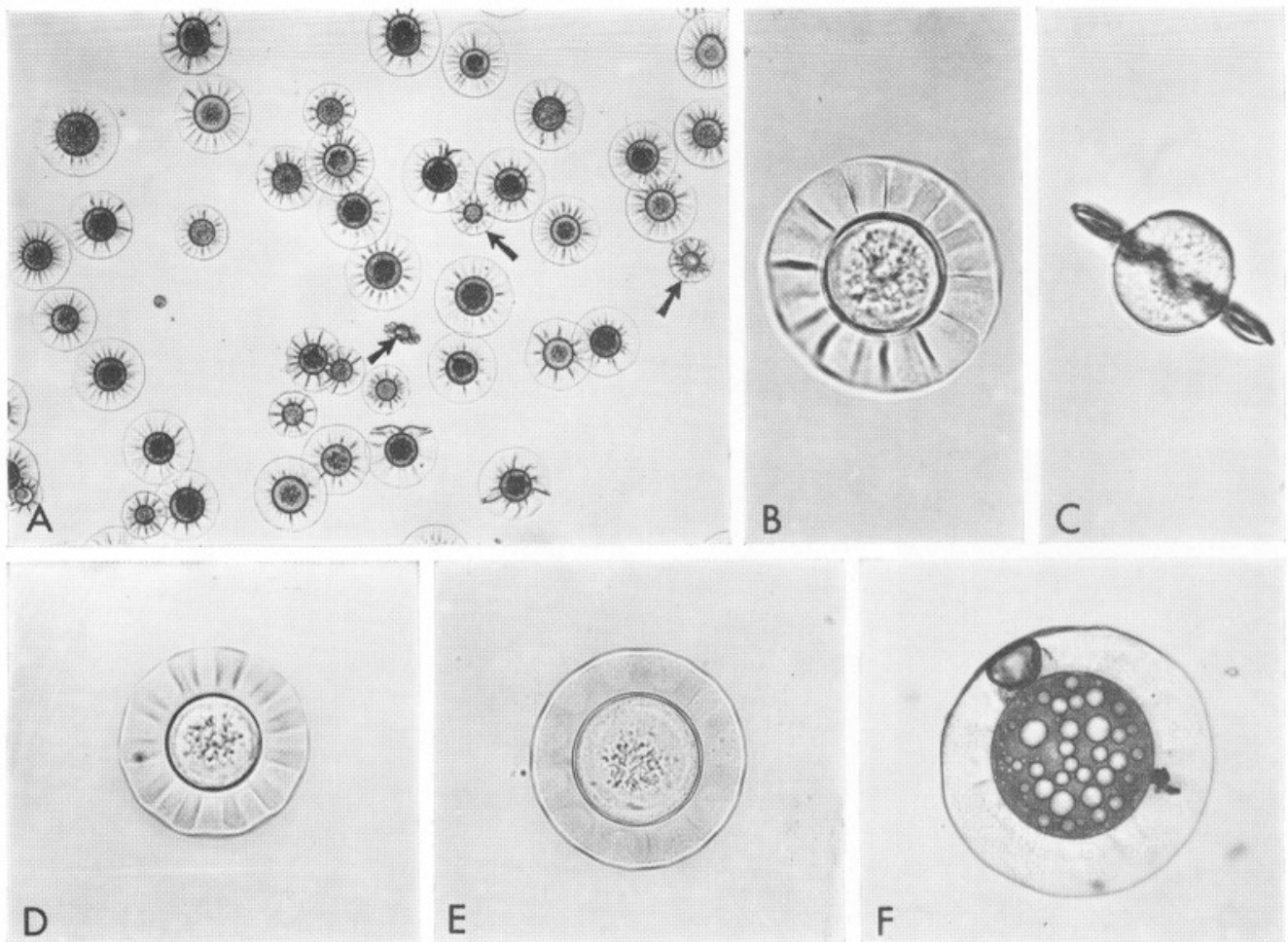

E
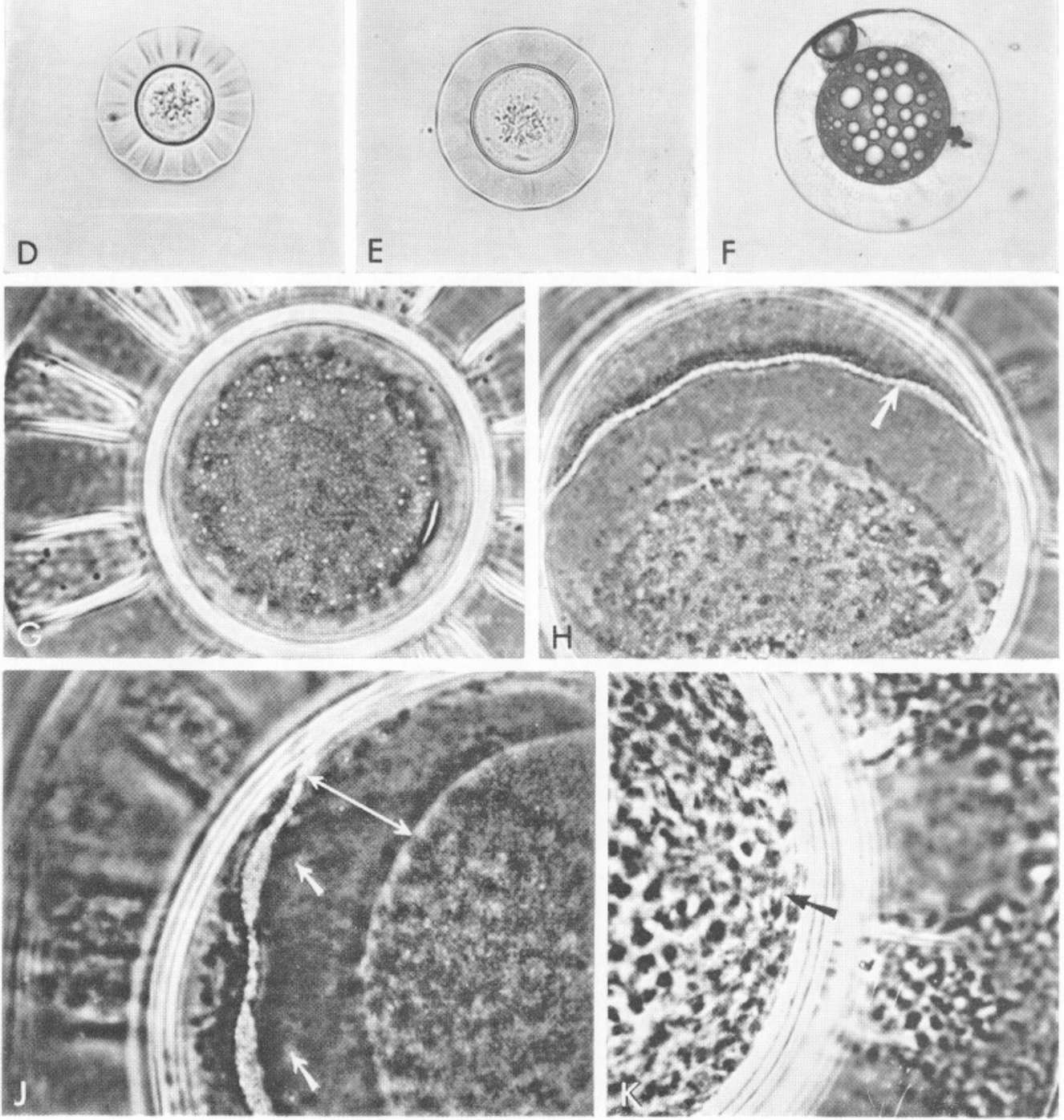

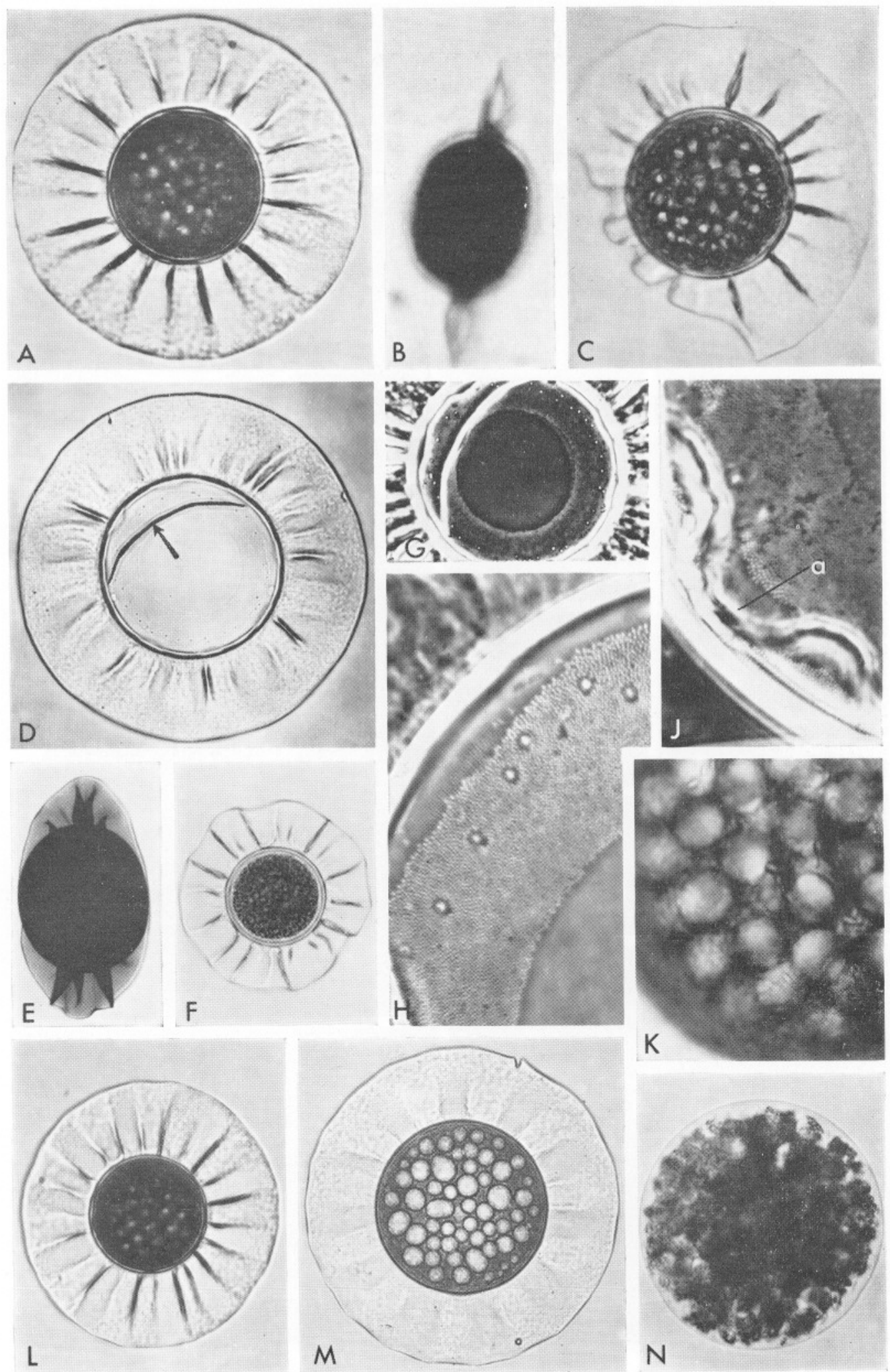

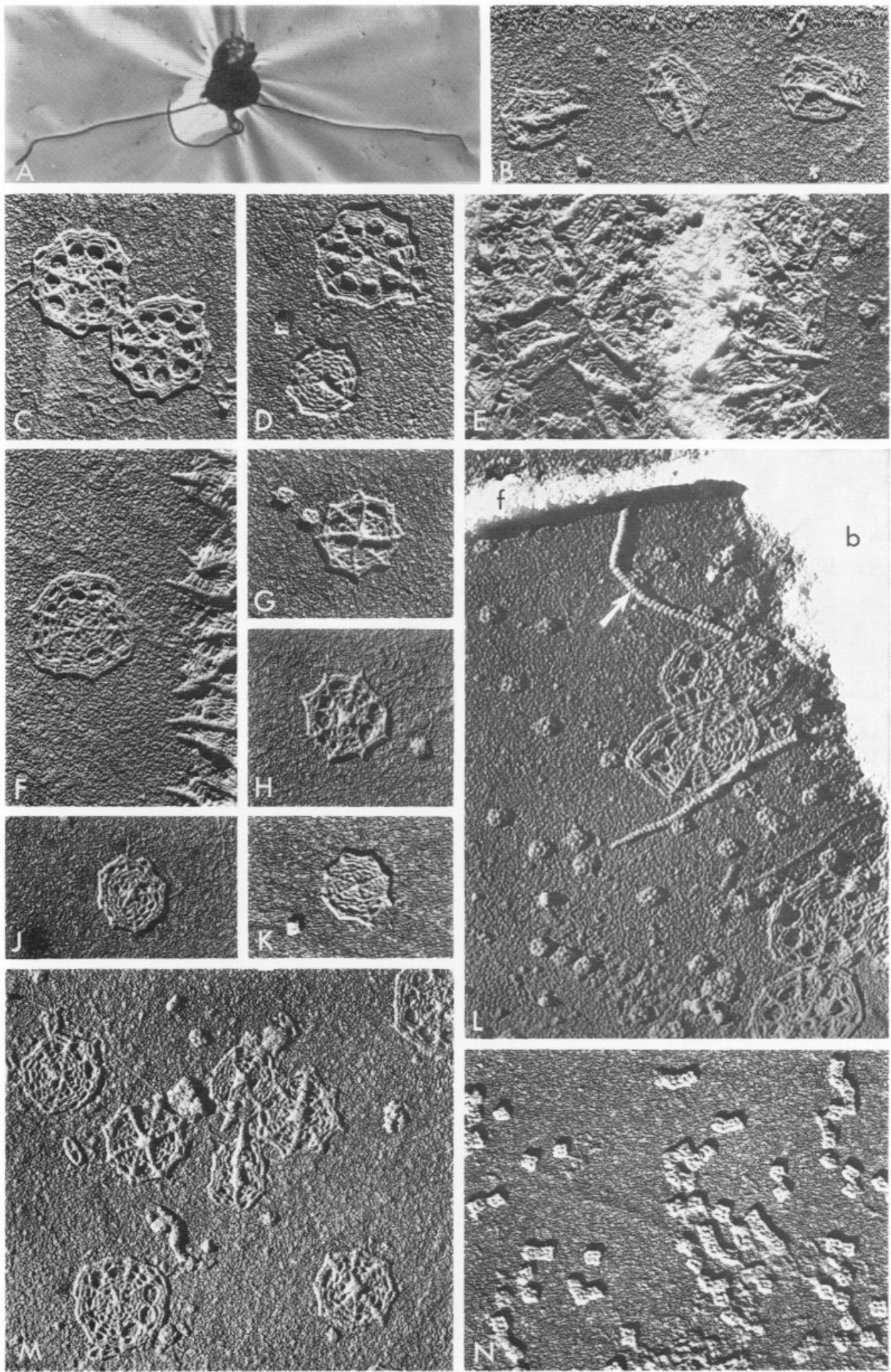


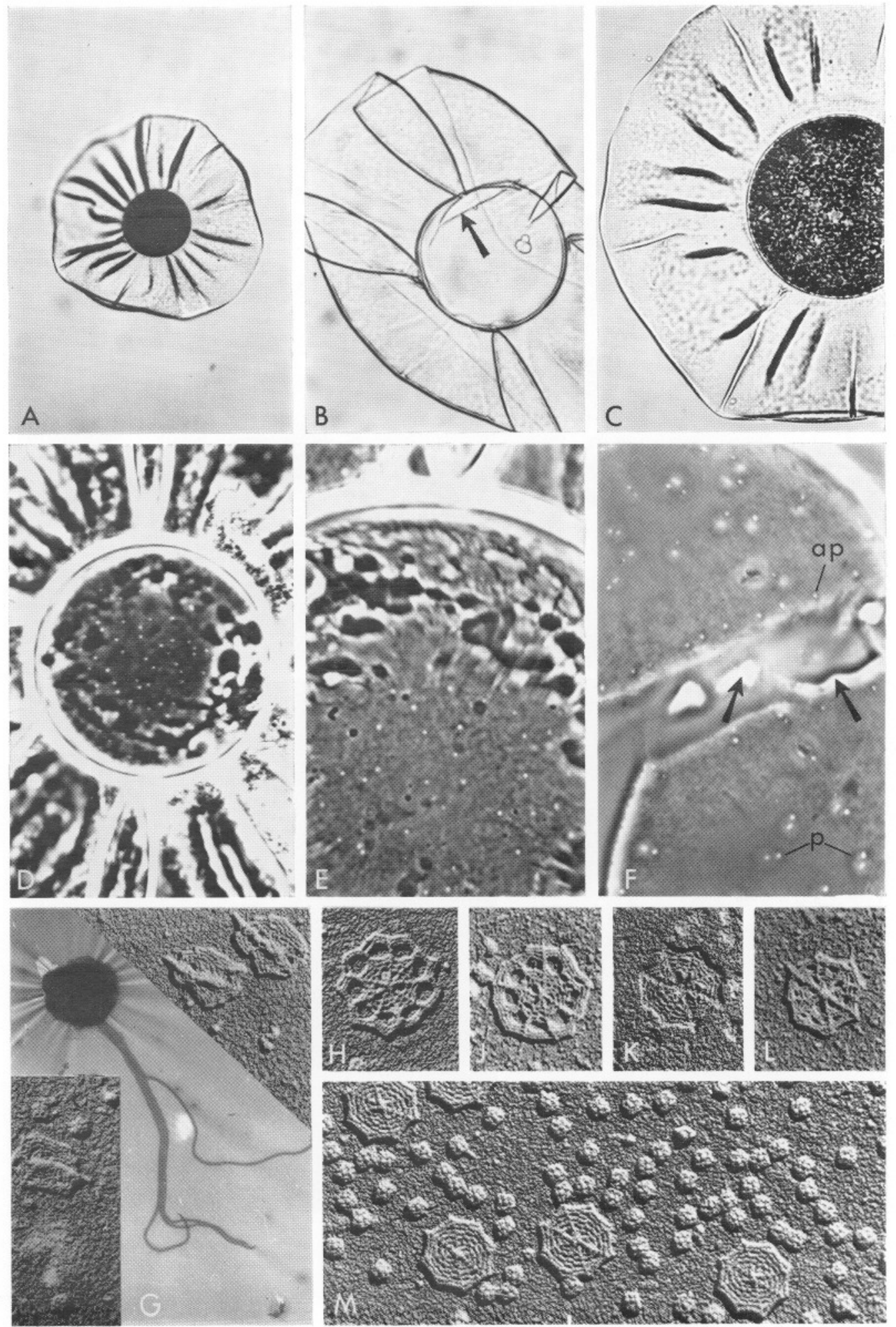



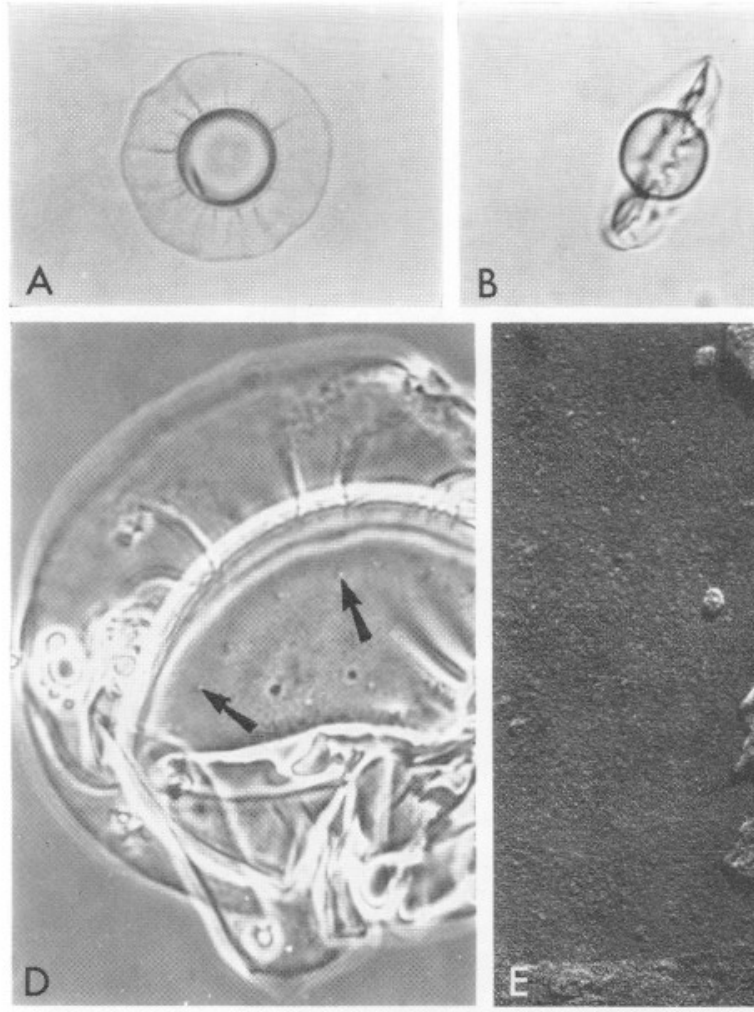

B
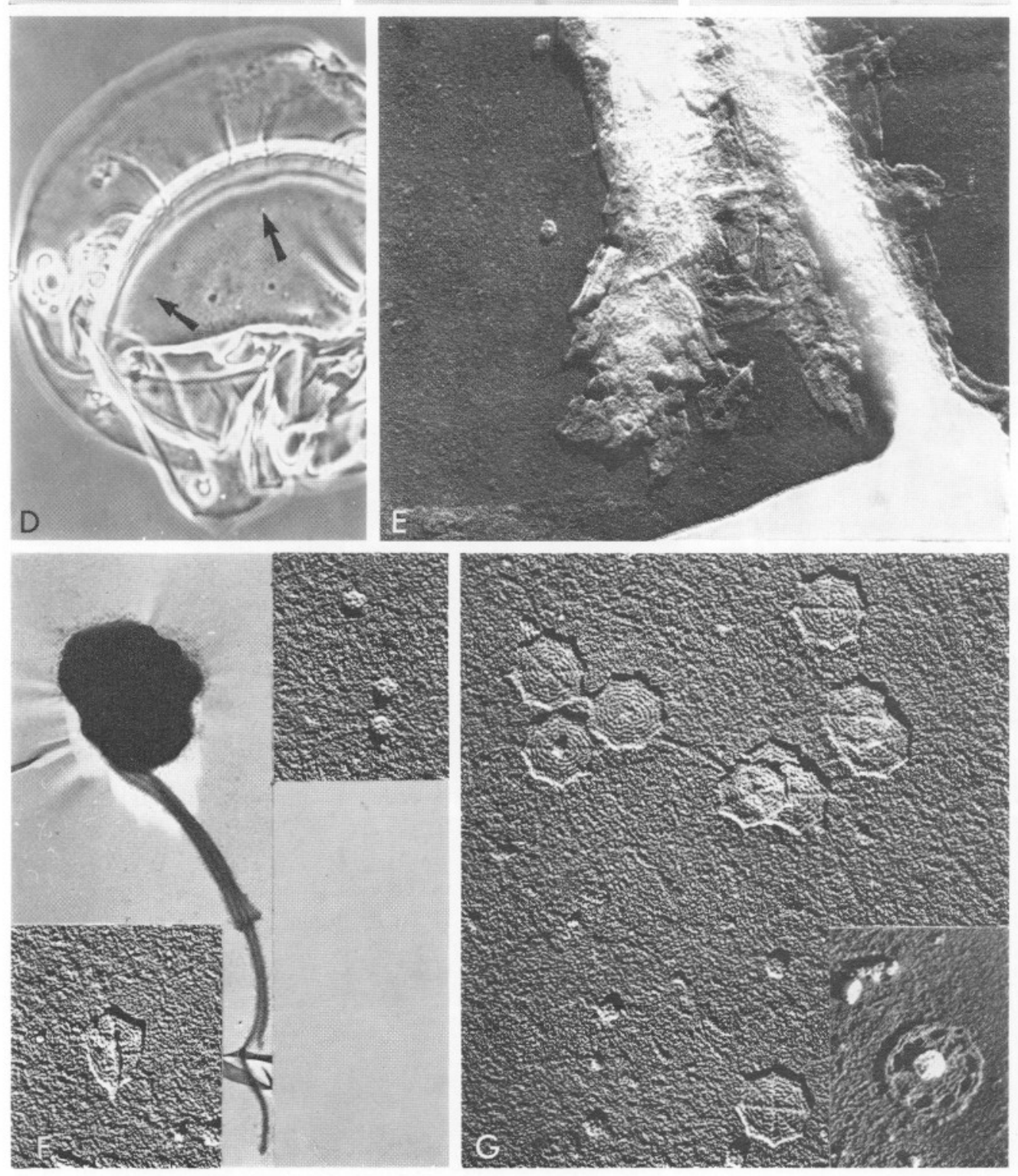

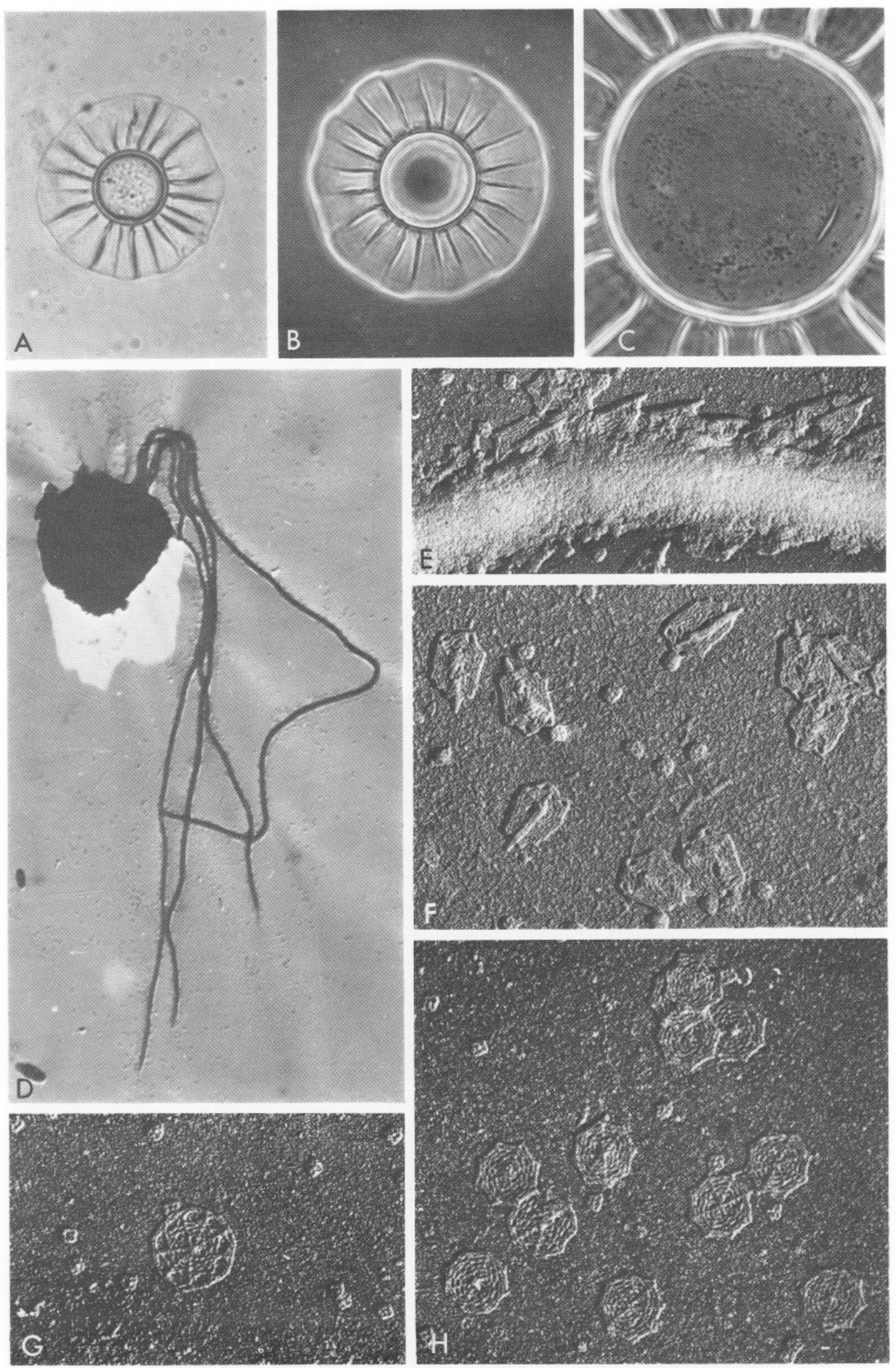

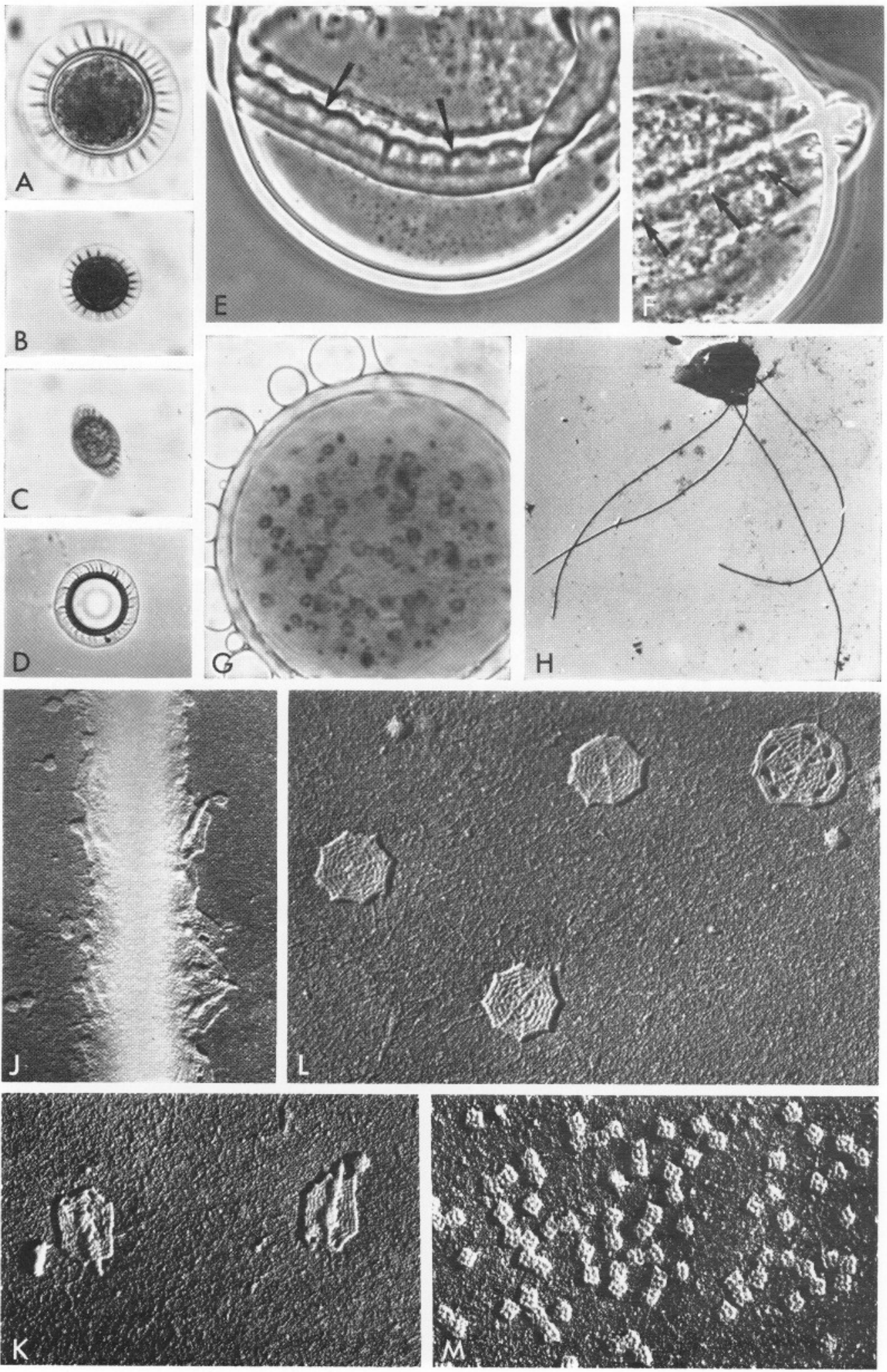
J. MAR. BIOL. Ass. U.K., 58 (1)
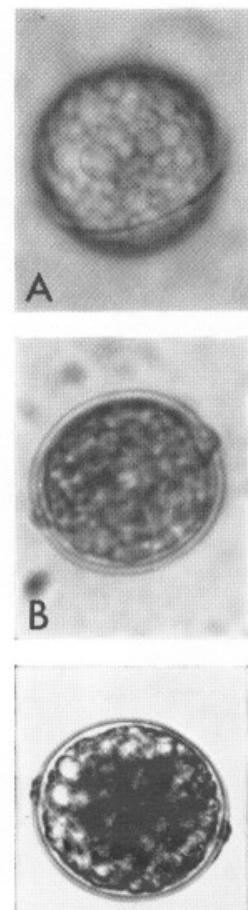

C

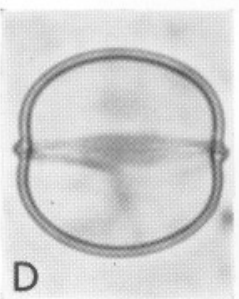

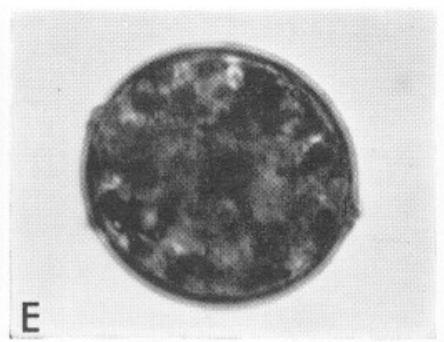
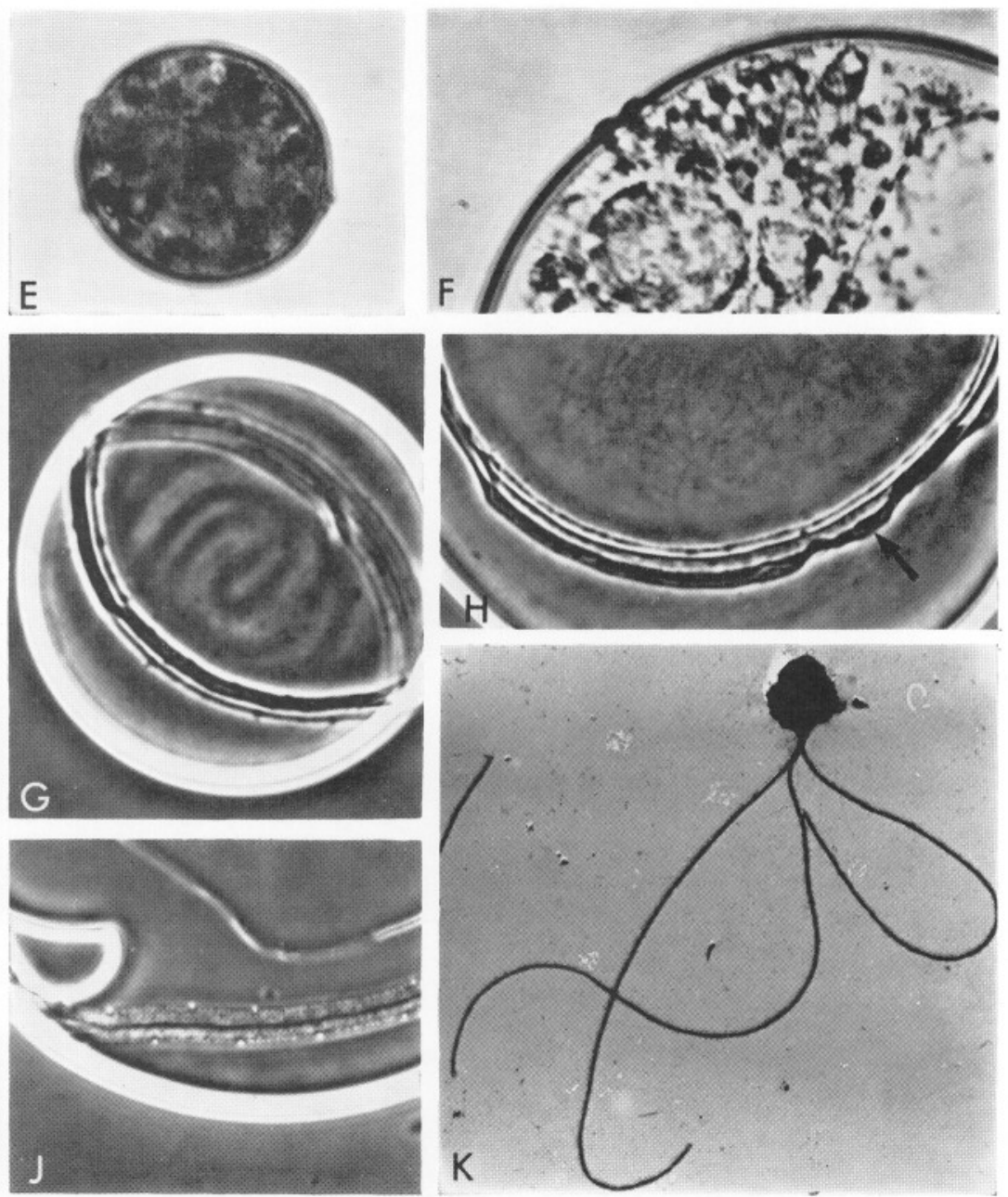
J. MAR. BIOL. Ass. U.K., 58 (1)

PARke \& Others. PLATE XIV

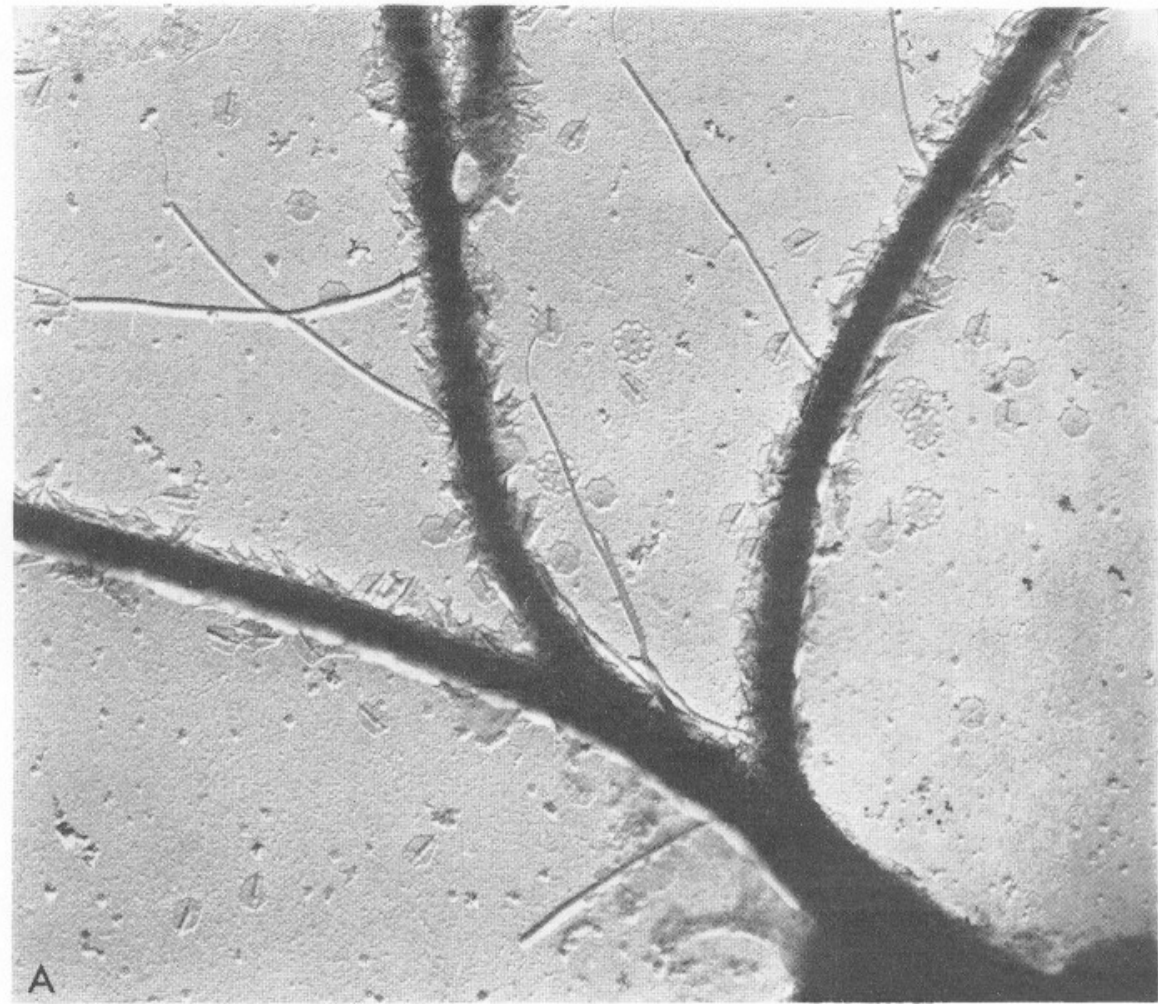

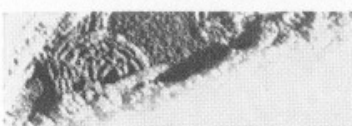

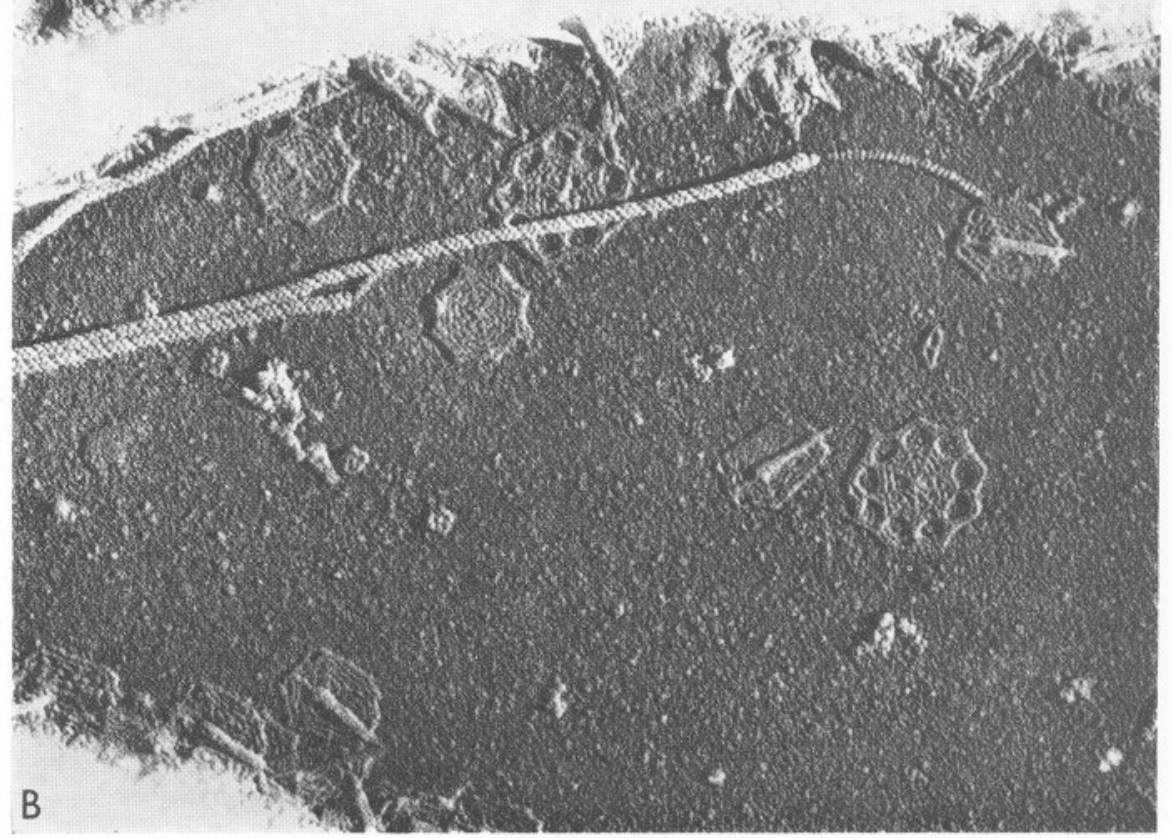


WETZEL, O., 1933. Die in organischer Substanz erhaltenen Mikrofossilien des baltischen KreideFeuersteins mit einem sedimentpetrographischen und stratigraphischen Anhang. Palaeontographica, A, 78, 1-110.

WetZEL, W., 1952. Beitrag zur Kenntnis des Danzeitlichen Meeresplanktons. Geologische fahresberichte, 66, 391-421.

\section{EXPLANATION OF PLATES I-XIV}

\section{Plate I}

(A) Pterosperma cuboides Gaarder first recorded for the Plymouth region 4 Nov. 1965; phycoma with six quadrangles. P107.56, $\times 450$.

(B) P. nationalis Lohm. - empty outer wall of phycoma with six quadrangles. P92.8, $\times 300$.

(C) $P$. citriforme sp.nov., Parke, a species with an exceptionally narrow equatorial ala. B63.15, $\times 450$.

(D) Two Pterosperma species each with a wide equatorial ala, P. moebii (Jørg.) Ostenf. and P. eurypteron sp.nov., Parke (bottom left). March 1964, from colour transparency, $\times 100$.

(E) Pterosperma species (designated 'Blocks IV') - empty outer wall of phycoma showing polygons and pores. B94.30, $\times 450$.

(F) P. marginatum Gaarder - empty outer wall of phycoma showing polygons, each with a large central ornamental pore. $\mathrm{P} 98.66, \times 450$.

(G) P. vanhoeffenii (Jørg.) Ostenf. - empty outer wall of phycoma showing pores and the wide alae forming four triangular fields on the body. Material collected from Drøbak, Oslo Fjord, Norway on 28 Apr. 1966, contents released at Plymouth 11 May 1966. P117.27, $\times 300$.

(H) $P$. polygonum Ostenf. - empty outer wall of phycoma showing polygons and pores. B89.10, $\times 1000$.

(J) Part of a full phycoma of $P$. moebii photographed close to alaband to illustrate that the papillate zone on the outer wall of the full phycoma can be detected if the wall surface is examined above a large lipid globule. B62.34, $\times 1500$.

(K) Pterosperma phycoma ('Blocks IV') squashed to release contents; note large numbers of lipid globules present. B95.20, phase, $\times 150$.

(L) Surface of outer wall of $P$. nationalis Lohm. phycoma showing pores. B65.3, phase, $\times 1500$.

\section{Plate II}

Pterosperma nationalis Lohm. except $\mathrm{H}$.

(A) Young phycoma with one central large lipid globule. B119.23, $\times 300$.

(B) Young phycoma with two central lipid globules. P87.2, $\times 300$.

(C) Young phycoma with dividing plastids lying peripherally to large lipid globule. B119.7, $\times 300$.

(D) Young phycoma immediately after rapid size increase before contents have divided to fill body of phycoma; large central lipid globule still present. B104.7, $\times 300$.

(E) Nearly mature phycoma; inner wall not yet thickened preparatory to release of contents. P67.31, $\times 300$.

(F) Nearly mature phycoma grown in culture with inner wall thickening prior to release of contents. P87.6, $\times 300$.

(G) Contents of immature phycoma, artificially released by pressure, showing inner wall (i) full of contents increasing in diameter as it is released from the outer wall (o). $\mathrm{P}_{71.2}, \times 300$.

(H) Immature Pterosperma phycoma (designated 'Blocks I') with large central lipid globule and smaller globules and plastids surrounding it. B119.24, $\times 1000$.

(J) Later stage than (H) with lipid content further divided up and central mass nearly gone. P119.29, $\times 300$.

(k) Part of an immature phycoma at a higher magnification than $(\mathrm{J})$ showing the small plastids around and between the lipid globules. B105.9, $\times 600$.

(L) Surface of part of the outer wall of an immature phycoma in focus to show pores and beneath the plastids and lipid globules. B105.8, $\times 600$.

(M) Part of an immature phycoma taken at a higher magnification to show pores in outer wall and lipid globules plus plastids with pyrenoids beneath inside inner wall. B105.17, $\times 1500$. 
(N) Contents of a mature phycoma artificially extruded by pressure; contents divided into eight masses inside inner wall, each mass containing one nucleus and numerous plastids and very small lipid globules. $\mathrm{P}_{71.8}, \times 600$.

\section{Plate III}

(A) Pterosperma nationalis small mature phycoma, $40 \mu \mathrm{m}$ diameter, just starting to liberate inner wall with its contents from the outer wall on 27 Feb. 1968. P127.23, $\times 300$.

(B) P. citriforme sp.nov. phycoma immediately after liberation on 29 Feb. 1968 of inner wall ( $40 \mu \mathrm{m}$ diam.) from outer wall (27 $\mu \mathrm{m}$ diam.). P127.55, $\times 300$.

(c) P. marginatum phycoma immediately after liberation on 27 Feb. 1968 of inner wall ( $67 \mu \mathrm{m} \mathrm{diam}$.), with contents starting to divide into four, from outer wall $(34 \mu \mathrm{m} \mathrm{diam}$.). P127.88, $\times 300$.

(D) P. marginatum phycoma with inner wall ( $54 \mu \mathrm{m}$ diam.) released from outer wall (34 $\mu \mathrm{m}$ diam.); contents of inner wall nearly separated into four. P127.7, $\times 300$.

(E) $P$. porosum sp.nov. phycoma after liberation on 16 Mar. 1970 of inner wall the contents of which are starting the third division into eight parts. B90.18, $\times 300$.

(F) P. moebii small phycoma photographed one hour after the release of the inner wall from the outer wall (total diam. $60 \mu \mathrm{m}$ ); content of inner wall divided into eight separated masses. B71.20, phase, $\times 300$.

(G) P. moebii large phycoma (note lower magnification) immediately after liberation on 3 Mar. 1969 of inner wall, with contents just starting division, from outer wall; release slit obvious in outer wall. B71.7, $\times 120$.

(H) P. nationalis empty outer wall of phycoma showing slit (arrowed) through which inner wall with contents was released on 18 May 1962 . $\mathrm{P}_{71.48}$, darkfield, $\times 300$.

(J) P. nationalis outer and inner walls of a phycoma $24 \mathrm{~h}$ after release of inner wall on 21 June 1972, the contents are dividing into 64 masses. B108.10, $\times 30$.

(K) $P$. nationalis - one of the dividing masses from inside an inner wall released on 13 June 1962; note large numbers of lipid globules present in each section. $\mathrm{P}_{74} .68, \times 300$.

(L) $P$. nationalis - one of the dividing masses from inside an inner wall $(120 \mu \mathrm{m}$ diam.) released on 26 Feb. 1968 at a later stage of fission than in $(\mathrm{K})$; the masses now dividing into fours with flagella developed. P126.39, $\times 300$.

(M) $P$. cuboides phycoma more than $48 \mathrm{~h}$ after liberation on $18 \mathrm{Dec} .1968$ of inner wall from outer wall; the contents ready to be released as motile cells. Note sizes of outer and inner walls which illustrate the great expansion of the inner wall after its release from the outer wall. B56.8, $\times 50$.

(N) P. nationalis - part of a phycoma inner wall liberated on 15 May $1962,470 \mu \mathrm{m}$ in diameter; contents dividing into fours $\mathrm{cf}$. (L). $\mathrm{P}_{71}$.40, darkfield, $\times 300$.

(P) P. nationalis - part of a phycoma inner wall full of motile cells $48 \mathrm{~h}$ after liberation from outer wall on 7 May 1963 and just prior to the release of the motile cells. $P_{78} .58$, darkfield, $\times 300$.

(Q) P. nationalis - cells of motile phase, fixed in $\mathrm{KI}_{3}$, inside a phycoma inner wall. $\mathrm{P} 78.64$, darkfield, $\times 300$.

\section{Plate IV}

\section{Pterosperma - motile phase}

(A) Pterosperma sp. (designated 'Blocks I') - cell of the motile phase. B95.10, phase $\times 400$.

(B) P. citriforme sp.nov. cell of the motile phase. B86.24, phase, $\times 375$.

(c) Pterosperma sp. - cell of the motile phase at higher magnification to show plastid (p), pyrenoid with surrounding starch shell (py) and lipid globule (1). B81.30, phase, $\times 1000$.

(D) $P$. nationalis motile cell in very early fission stage fixed in $\mathrm{KI}_{3}$, showing insertion of flagella on body (arrow) and presence of two pyrenoids. $P_{71.18}$, darkfield, $\times 1000$.

(E) $P$. nationalis motile cell in early fission stage, fixed in $\mathrm{KI}_{3}$, showing four parent flagella and daughterflagella $3 \mu \mathrm{m}$ long (arrow) just starting to develop. P71.30, darkfield, $\times 1000$.

(F) P. nationalis motile cell with body directed forward in attitude characteristic for rapid swimming. P92.63, darkfield, $\times 375$.

(G) P. nationalis motile cell attaching by its four long flagella in attitude characteristic for the genus when cells of the motile phase are 'dancing' or showing vibration of the cell body. P92.67, darkfield, $\times 375$.

(H) $P$. nationalis motile cell in fission stage showing broadening of body and full development of the four daughter-flagella. P72. 26, darkfield, $\times 375$. 
(J) P. nationalis motile cell in later stage of fission than in ( $\mathrm{H}$ ), fission of body commenced. $\mathrm{P}_{92} .69$, darkfield, $\times 375$.

(K) P. nationalis late fission stage of motile phase showing the two daughter-cells about to separate. $\mathrm{P}_{72.18}$, darkfield, $\times 375$.

(L) P. nationalis - part of a flagellum to show the presence of underlayer small scales, outer layer spined scales and hairs on the flagella of the motile phase. Micrograph PE64.11, $\times 34000$.

(M) Different types of body scales occurring on cells of the motile phase in the genus Pterosperma; small square scales (bottom) from innermost scale layer on the body. Micrographs PE29.16, PE56.26, × 30000 .

\section{Plate V}

(A) Pterosperma nationalis empty outer phycoma wall of form (4), with 5 quadrangular and 2 pentangular fields (see p. 251). P92.90, $\times 300$.

(в) P. nationalis empty outer phycoma wall of form (2), with 6 quadrangular fields (see p. 251). P98.58, $\times 300$.

(c) $P$. nationalis empty outer phycoma wall of form (3), with 2 triangular and 3 quadrangular fields (see $\mathrm{p}$. 251). P126.67, $\times 300$.

(D) P. nationalis empty outer phycoma wall of form (1), with 4 triangular fields (see p. 251). P112.8, darkfield, $\times 300$.

(E) P. vanhoeffenii empty outer phycoma wall of form (1), with 4 triangular fields. B19.4, $\times 300$.

(F) P. vanhoeffenii empty outer phycoma wall of form (3), with 2 triangular and 3 quadrangular fields. B19.18, $\times 300$.

(G) P. moebii nearly mature phycoma of the more usually occurring large size, compare size of phycoma in (H). B104.23, $\times 300$.

(H) P. moebii mature phycoma ready to release of the less frequently occurring small size at same magnification as (G) for size comparison. B83.12, $\times 300$.

(J) P. cuboides nearly mature small phycoma of form (2) with 6 quadrangular fields at same magnification as (L) for size comparison (see p. 252). P107.38, $\times 300$.

(K) P. cuboides empty outer phycoma wall of form (3), with 2 triangular and 3 quadrangular fields (see p. 252). B35.2, $\times 300$.

(L) P. cuboides empty outer phycoma wall of form (2), with 6 quadrangular fields; compare also size of phycoma in (J) (see p. 253). B56.3, $\times 300$.

\section{Plate VI}

Pterosperma rotondum Pouchet - phycoma phase

(A) Formalin preserved phycomata of $P$. rotondum (arrows) and $P$. moebii isolated from fine townet samples collected in the northern North Sea by Dr N. Reynolds Aug.-Sept. 1968. B69.24, ×60.

(B) Face view of a phycoma. B73.11, $\times 300$.

(C) Side view of a phycoma. B73.12, $\times 300$.

(D) Phycoma not under cover-slip pressure, compare with (E). B79.14, $\times 300$.

(E) The same phycoma as (D) under pressure of coverslip; note change in overall area and in ala/body proportions. B79.17, $\times 300$.

(F) Phycoma under cover-slip pressure showing lipid globules inside body and also one globule extruded into the ala. Compare this micrograph with copy of Pouchet's original drawing (1893, fig. 18 A) illustrated in Fig. 1 on page 242. B69.32, $\times 160$.

(G) Phycoma body showing the broad coarsely papillose band on body wall adjacent to alaband and the spaced clearly defined pores on remainder of body wall. B73.21, $\times 1250$.

(H) Phycoma, under cover-slip pressure, showing alaband pores and insertion of ala (arrow) in slight undulations on alaband. B79.19, phase, $\times 1250$.

(J) Phycoma, under cover-slip pressure, to show the coarsely papillose band (double-headed arrow across width of band) in which alaband pores (arrows) are situated close to the insertion of the ala. B73.16, phase, $\times 1600$.

(K) Part of a phycoma in which the coarsely papillose region of the outer wall close to the alaband is just visible (arrow). B58.32, phase, $\times 1000$. 


\section{Plate VII}

Pterosperma moebii (Jørg.) Ostenf. - phycoma phase

(A) Phycoma in face view showing body and equatorial ala. B70.7, ca. $\times 300$.

(B) Phycoma in side view showing flattened poles; not under pressure-focus poor as phycoma moving. P60.7, $\times 300$.

(C) Phycoma showing the undulations in torn part of the ala. P46.54, $\times 300$.

(D) Empty phycoma outer wall showing slit (arrow) through which contents were released. B62 .6, ca. $\times 300$.

(E) Phycoma rolled over and under cover-slip pressure; compare copy of Pouchet's illustration of $P$. ovatum (Pouchet 1893, fig. 18B) in Fig. 1 on page 242. B71.3, $\times 300$.

(F) Phycoma grown in culture; changed over from motile phase Feb. 1970, photographed 23 April 1970. B91.17, $\times 300$.

(G) Empty outer wall of phycoma showing release slit, alaband pores and papillate zone on wall. B62.8, phase, $\times 300$.

(H) Part of (G) at a higher magnification to show details of pores and papillate zone. B62.9, phase, $\times 1250$.

(J) Part of a phycoma outer wall showing origin of ala (a), in undulations, from the alaband. B61.10, phase, $\times 1250$.

(K) Part of a phycoma showing lipid globules and small plastids. P44.30, $\times 600$.

(L) Phycoma not under cover-slip pressure, compare with M. B70.7, × 200.

(M) The same phycoma as (L) under pressure of cover-slip; note change in overall area and in ala/body proportions. B71.10, $\times 200$.

(N) A phycoma inner wall, with its contents dividing to produce motile cells, after its release from the outer phycoma wall. B90.4, $\times 300$.

\section{Plate VIII}

Pterosperma moebii (Jørg.) Ostenf. - motile phase

(Reversed prints, $\times 40000$, except A.)

(A) Cell soon after fission with its two daughter-flagella not yet grown to full length. Micrograph PE 70.20 , $\times 2000$.

(B) Scales from the outer scale layer of the flagellum showing outer surface with adnate spine and inner surface lacking spine. Micrograph PE 68.22.

(c) Type 2 body scales - outermost striae curved to give scalloped appearance (see p. 249). Micrograph PE 50.51 .

(D) Types 2 and 4 body scales with small square scale from innermost layer of body scales for size comparison. Micrograph PE 50.30.

(E) Part of a flagellum showing under layer small scales and outer layer spined scales. Micrograph PE 68.12.

(F) Type 1 body scale recorded so far only in P. moebii (see p. 248). Micrograph PE 68.19.

(G, H) The two sides of type 3 body scales (see p. 249). Micrograph PE 50.33.

(J, K) The two sides of type 4 body scales (see p. 248). Micrographs PE 50.33 and 35 .

(L) Four body scales of type 1 (compare F.) lying close to flagellum (f) emerging from body (b). Note the striated hairtips (arrow) of the large type of flagellar hair (see Pl. XIV B) which is developed close to the flagellar bases. Micrograph PE 89.41.

(M) Body and flagellar scales showing comparative sizes. Micrograph PE 68.32.

(N) Small four-lobed scales from the innermost scale layer around the body. Micrograph PE 56.35.

\section{Plate IX}

\section{Pterosperma eurypteron sp.nov., Parke}

(A) Phycoma in face view showing body and equatorial ala. B59.6, $\times 160$.

(B) Empty outer wall of a phycoma, with ala in folds, showing slit (arrow) though which contents were released. $\mathrm{P}_{91.41} \times 300$.

(c) Part of a mature phycoma showing characteristic appearance of the ala. Body contents ready for fission and release. B59.18, $\times 300$. 
(D) Body of an immature phycoma to show the spaced, clearly defined, pores in the outer wall. B63.1, $\times 500$.

(E) Part of same phycoma as (D) at higher magnification. B63.2, $\times 1260$.

(F) Part of a squashed phycoma showing alaband (arrow on left), torn ala (arrow on right) arising from it, ring of alaband pores (ap) and outer wall pores (p) frequently in pairs close to alaband. B69.2, × 1260.

(G) Cell of the motile phase. Micrograph PE 57.1, $\times 1000$. Top right inset - scales from the outer scale layer of the flagellum showing inner surface lacking spine. Bottom left inset - small five-lobed scales from under layer of flagellar scales and outer surface of a spined scale showing adnate spine. Insets micrograph PE 70.16 , reversed prints, $\times 40000$.

$(\mathrm{H}, \mathrm{J})$ Type 2 body scales - outermost striae curved to give scalloped appearance (see p. 249). Micrographs $\mathrm{PE}_{58.4}$ and $\mathrm{PE}_{70.14}$, reversed prints, $\times 40000$.

(K, L) Two type 3 body scales (see p. 249) showing the same side but with slightly different patterning. Micrographs PE70.10 and 14 , reversed prints, $\times 40000$.

(м) Type 4 body scales (see p. 249) and small four-lobed scales from the innermost layer of body scales. Micrograph PE57.15, reversed print, $\times 40000$.

\section{Plate X}

\section{Pterosperma porosum sp.nov., Parke}

(A) Empty outer wall of a phycoma in face view showing release slit in body. B90.25, $\times 38$.

(B, C) Empty outer wall of a phycoma in side view at different focal levels. B80.28 and $29, \times 300$.

(D) Outer wall of a phycoma squashed to show the ring of spaced pores (arrows) lying, in each hemisphere, some distance away from the insertion of the equatorial ala. B89.17, $\times 1260$.

(E) Part of a flagellum showing the covering of scales. Micrograph PE85.9, $\times 30000$.

(F) Cell of the motile phase immediately after fission with its two daughter-flagella not yet grown to full length; note loose scales around body and flagella. PE85.1, $\times 2000$. Top right inset - small five-lobed scales from under layer of scales on the flagellum. Bottom left inset - spined scale from outer scale layer of the flagellum. Insets micrograph PE90.28, reversed prints, $\times 30000$.

(G) The two sides of type 4 body scales (see p. 249) and two small four-lobed scales (bottom left) from innermost layer of body scales. Micrograph PE90.28, reversed print $\times 30000$. Bottom right inset - type 2 body scale. Micrograph PE86.29, reversed print, $\times 30000$.

\section{Plate XI}

Pterosperma inornatum sp.nov., Parke

(A) Phycoma in face view showing body and equatorial ala - not under pressure from cover-slip. B97.8, $\times 500$.

(B) Phycoma in face view under pressure from cover-slip. B97.13, phase, $\times 500$.

(c) Empty phycoma outer wall to show zones of fine and coarse rugosity on wall surface; note slit in wall through which contents were released. B97.16, phase, $\times 1260$.

(D) Cell of the motile phase, numerous scales from flagella and body scattered over the field. Micrograph PE69.13, $\times 2000$.

(E) Part of a flagellum to illustrate the overlapping of the spined outer layer scales. Micrograph PE69.8, reversed print, $\times 40000$.

(F) Details of flagellar scales from the two scale layers. Micrograph PE69.14, reversed print, $\times 40000$.

(G) Type 2 body scale (see p. 249) and small four and five-lobed scales from the innermost layer of body and flagella scales respectively. Micrograph PE69.18, reversed print, $\times 40000$.

(H) The two sides of type 4 body scales (see p. 249) and small four-lobed body scales from the motile phase. Micrograph PE69.16, reversed print, $\times 40000$.

\section{Plate XII}

Pterosperma undulatum Ostenf.

(A) Phycoma in face view under pressure from cover-slip. P117.51, $\times 600$.

(B) Phycoma in face view, not under pressure from cover-slip. P117.45, $\times 300$.

(C) Phycoma almost in side view, not under pressure from cover-slip P121 .16, $\times 300$.

(D) Outer wall of a phycoma from which contents have been released naturally. B10.13, $\times 300$. 
(E) Phycoma to show the undulate attachment of the ala (arrows) on lighter toned alaband; width of ala clearly visible where it folds over on right of figure. B67.16, phase, $\times 1260$.

(F) Part of a phycoma showing alaband pores (arrows). B80.14, phase, $\times 1260$.

(G) Phycoma treated with $\mathrm{KI}_{3}$ to show up presence of starch shells around the pyrenoids; note also numerous globules of lipid material passing out from body into the ala due to cover-slip pressure. P115.89, $\times 1000$,

(H) Cell of the motile phase. Micrograph PE89.37, $\times 1000$.

(J) Part of a flagellum showing underlayer small scales and some spined scales from the outer layer. Micrograph $\mathrm{PE}_{51} 1.8$, reversed print, $\times 30000$.

(к) Two spined flagellar scales, left-hand scale showing under surface. Micrograph PE51.32, reversed print, $\times 40000$.

(L) Type 2 body scale (top right) and both sides of type 4 body scales (see p. 249). Micrograph PE51.30, reversed print, $\times 40000$.

(M) Small four-lobed scales from the innermost layer of body scales. Micrograph PE51.16, reversed print, $\times 40000$.

\section{Plate XIII}

\section{Pterosperma citriforme sp.nov., Parke}

(A) Immature phycoma with outer edge of ala in focus. P98.14, $\times 450$.

(B) Phycoma showing outer and inner walls; equatorial ala just visible. $\mathrm{P}_{114} .6, \times 450$.

(C) Phycoma in side view with raised margins of alaband in focus in optical section giving the 'citriforme' appearance. B63.9, $\times 450$.

(D) An empty phycoma outer wall from which the inner wall with its contents had been released naturally. P126.11, $\times 450$.

(E) Immature phycoma after treatment with $\mathrm{KI}_{3}$; starch shells around pyrenoids appearing as dark masses. P114.38, $\times 600$.

(F) Part of a phycoma in optical section to show raised margins of alaband. B60.3, $\times 1260$.

(G) Empty phycoma outer wall showing alaband with alaband pores and the very narrow ala (dark band). B59.32, phase, $\times 1260$.

(H) Part of alaband and ala (arrow) of empty phycoma outer wall under cover-slip pressure. B63.22, phase $\times 1260$.

(J) Part of alaband of empty phycoma outer wall showing coarse rugosity of alaband margins which contain the clearly discernible alaband pores. B63.19, phase, $\times 1260$.

(K) Cell of the motile phase showing the long hairs present on the proximal regions of the flagella; one flagellum cast during fixation of cell. Micrograph PE89.22, $\times 1000$.

\section{Plate XIV}

\section{Pterosperma citriforme sp.nov., Parke}

(A) Proximal region of the flagella of a motile cell to show under layer of small and outer layer of spined scales from the flagella, types 2 and 4 body scales (see p. 249) and the long striated hairs arising from the flagella. Micrograph PE89.24, × 13000 .

(B) Part of (A) showing details of scales and the striated hairs. Micrograph PE89.25, reversed print, $\times 40000$. 